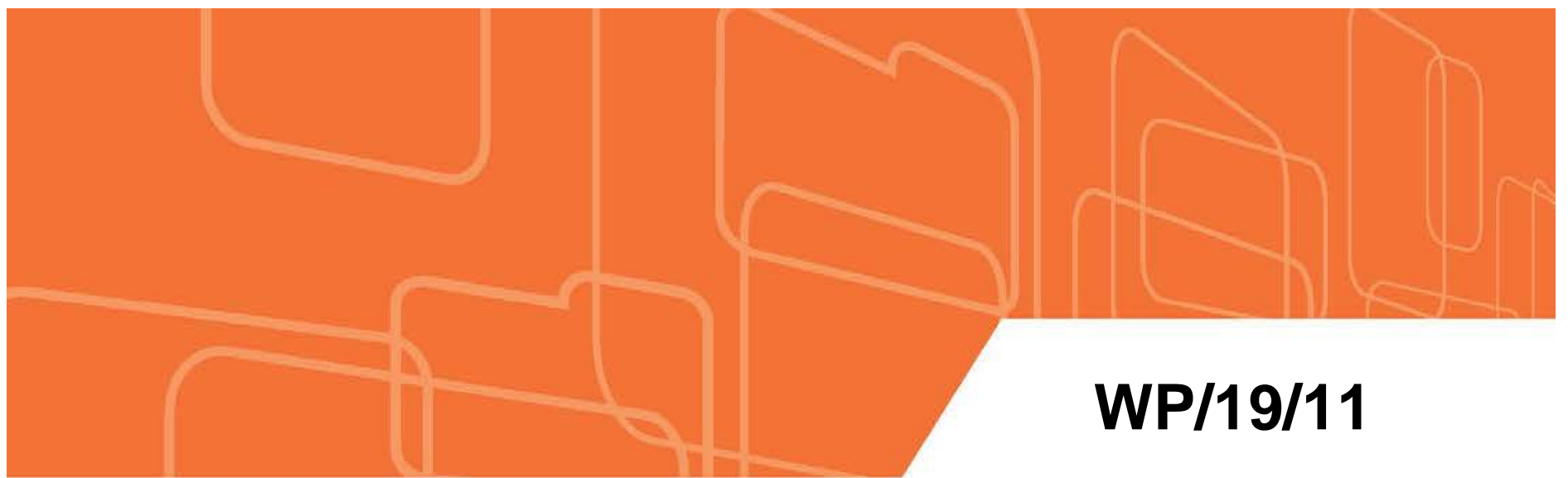

IMF Working Paper

\title{
Has Higher Household Indebtedness Weakened Monetary Policy Transmission?
}

by Gaston Gelos, Federico Grinberg, Tommaso Mancini-Griffoli, Shujaat Khan, Machiko Narita, and Umang Rawat

IMF Working Papers describe research in progress by the author(s) and are published to elicit comments and to encourage debate. The views expressed in IMF Working Papers are those of the author(s) and do not necessarily represent the views of the IMF, its Executive Board, or IMF management. 


\title{
IMF Working Paper
}

\author{
Monetary and Capital Markets Department
}

\section{Has Higher Household Indebtedness Weakened Monetary Policy Transmission?}

\author{
Prepared by Gaston Gelos, Federico Grinberg, Tommaso Mancini-Griffoli, Shujaat Khan, \\ Machiko Narita, and Umang Rawat ${ }^{1}$
}

January 2019

\begin{abstract}
IMF Working Papers describe research in progress by the author(s) and are published to elicit comments and to encourage debate. The views expressed in IMF Working Papers are those of the author(s) and do not necessarily represent the views of the IMF, its Executive Board, or IMF management.
\end{abstract}

\begin{abstract}
Has monetary policy in advanced economies been less effective since the global financial crisis because of deteriorating household balance sheets? This paper examines the question using household data from the United States. It compares the responsiveness of household consumption to monetary policy shocks in the pre- and post-crisis periods, relating changes in monetary transmission to changes in household indebtedness and liquidity. The results show that the responsiveness of household consumption has diminished since the crisis. However, household balance sheets are not the culprit. Households with higher debt levels and lower shares of liquid assets are the most responsive to monetary policy, and the share of these households in the population grew. Other factors, such as economic uncertainty, appear to have played a bigger role in the decline of households' responsiveness to monetary policy.

JEL Classification Numbers: E44, E52, D12

Keywords: Monetary policy, transmission, households, consumption, real estate, leverage Author’s E-Mail Address: ggelos@imf.org, fgrinberg@imf.org, sakhan@jhu.edu, tmancinigriffoli@imf.org, mnarita@imf.org, urawat@imf.org

\footnotetext{
${ }^{1}$ The authors are particularly grateful to Simon Gilchrist for helpful suggestions. Thanks are also due to Tobias Adrian, Zohair Alam, Chikako Baba, Majid Bazarbash, Luis Brandao Marques, Alan Feng, Mariam El Hamiani Khatat, Lucyna Gornicka, Thomas Harjes, Deniz Igan, Soledad Martinez-Peria, Thomas Piontek, Futoshi Narita, William Oman, Andrea Presbitero, Ratna Sahay, Damiano Sandri, Nico Valckx, Skander Van Den Heuvel, Miklos Vari, Pawel Zabczyk, and IMF seminar participants for useful comments. Editorial and production assistance by Sonia Maria Echeverri, Donna Tomas, and Janice Yi Xue is gratefully acknowledged.
} 
I. Introduction 4

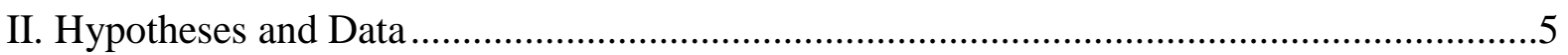

A. Data: Variables of Interest, Sources, and Summary Statistics ...................................6

B. Identifying Monetary Policy Shocks........................................................................

III. Has the Response of Household Consumption Changed Post-Crisis? ..................................9

IV. Does Household Indebtedness Matter? ...........................................................................14

V. Does Household Liquidity Matter?............................................................................18

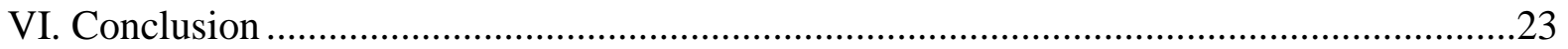

Tables

1. Non-Durable and Durable Consumption ..........................................................................

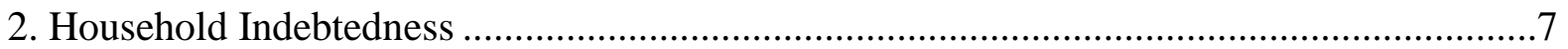

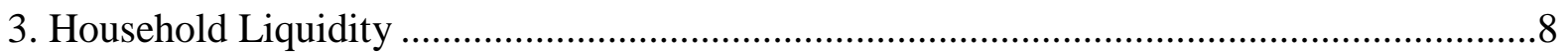

4. Impact of Monetary Policy on Consumption: Has it Changed ...........................................13

5. Impact of Monetary Policy on Consumption: The Role of Indebtedness............................15

6. Response of Growth to $10 \mathrm{bp}$ Increase in the 2-Year Yield at Different LTV Thresholds .17

7. Impact of Monetary Policy on Consumption: The Role of Liquidity..................................20

8. Response of Consumption Growth to a 10 Basis Point Increase in the................................21

9. Impact of Monetary Policy on Consumption: The Role of Uncertainty...............................23

\section{Figures}

1. Response of Durable and Non-Durable Consumption to Monetary Policy..........................11

2. Consumption Response to 10-Basis Point Increase in 2-Year Yield.....................................14

3. Effect of Monetary Policy on Consumption Growth at Different LTV Levels ....................16

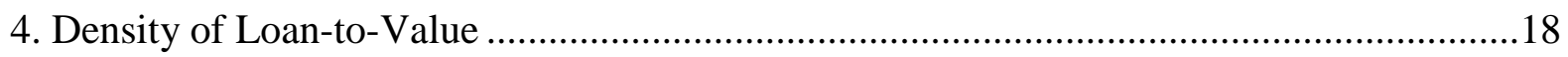

5. Effect of Monetary Policy on Consumption Growth at Different Liquidity Levels............21

6. Density of Liquid-Asset-to Income ..................................................................................21

\section{Appendices}

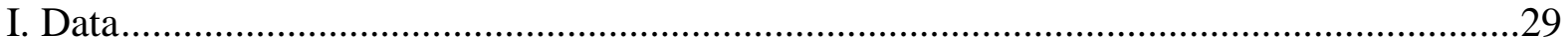

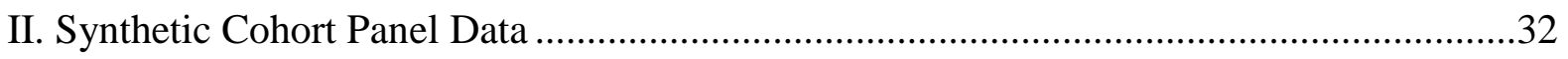

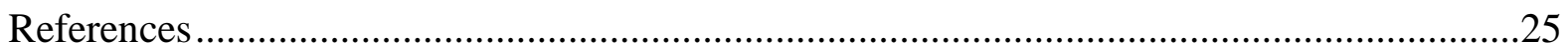




\section{INTRODUCTION}

A common perception among many academics and policymakers is that monetary policy in advanced economies has been less effective since the crisis because of higher household debt, and associated credit constraints. Amir Sufi summarized this view in 2015 (Sufi, 2015): "Monetary policy over the past seven years has been ineffective because it has channeled interest savings and additional credit to exactly the households that are least likely to change their spending in response. The households that would normally spend most aggressively out of monetary policy shocks are heavily indebted or have seen their credit scores plummet, rendering them either unwilling or unable to boost spending."

To date, however, the issue has - to our knowledge — not been systematically assessed. While a few studies have examined the role of household balance sheets in monetary transmission, they have focused on the pre-crisis period, and have not directly analyzed whether post-crisis debt levels have impeded transmission. ${ }^{2}$ These studies suggest that more indebted and less liquid households react more to monetary policy. The argument is that these households run into collateral and liquidity constraints, which monetary policy directly affects (Aldangady, 2014; Cloyne, Ferreira, and Surico, 2018; Di Maggio and others, 2017; Flodén and others, 2017, emphasize households' cash flows; Luo, 2017 focuses on households’ default risk). Using aggregate data, Hofmann and Peersman (2017) also find a stronger impact of monetary policy in economies with high private debt. One open question, however, is whether at very high debt levels, effects are different. In these cases, monetary easing may do little to alleviate credit constraints, and thus stimulate consumption (Alpanda and Zubairy, 2017; Sufi 2015). ${ }^{3}$ The responsiveness of households to monetary policy may thus display an inverted U-shaped pattern, rising as debt levels grow below a certain threshold, and declining thereafter.

In this paper we compare the transmission of monetary policy through household consumption in the pre- and post-crisis periods, and ask whether changes therein can be explained by the evolution of household balance sheets. To this end, we use quarterly household-level data from the U.S. Consumer Expenditure Survey (CEX) from 1996 to 2014. We first assess average changes in the responsiveness of household consumption to monetary policy shocks, which we identify using exogenous instruments drawn from high-frequency data, in the tradition of Bernanke and Kuttner (2005). We employ both synthetic cohort analysis (which enable us to obtain longer times series and derive local projections), and standard panel data methods that exploit the full micro data set. Next, we explore the role of

\footnotetext{
${ }^{2}$ Without discussing monetary policy effects, Mian, Rao, and Sufi (2013) and Kaplan, Violante, and Weidner (2014) find that leverage and liquidity significantly affect household's propensity to consume.

${ }^{3}$ Some empirical studies show adverse effects of high debt on consumption, although they do not examine monetary policy effects (such as Alter and others, 2018; Drehmann and others, 2017; Mian and others, 2017; Melzer, 2017; IMF, 2017; Dynan, 2012). Many studies highlight the adverse effect on aggregate demand from debt deleveraging caused by the housing crisis during the U.S. Great Recession (such as Eggertsson and Krugman, 2012; Mian and Sufi, 2014; Guerrieri and Lorenzoni, 2011; and Eggertsson and others, 2017).
} 
two household balance-sheet variables in driving cross-sectional differences in the responses to monetary policy shocks: indebtedness (mortgage balance relative to house value), and liquidity (liquid assets to monthly income). ${ }^{4}$

We show that the response of household consumption to monetary policy shocks has diminished since the global financial crisis. We also find that higher-indebted households tend to respond more to monetary policy shocks—-particularly relative to durable consumption - in the pre- and post-crisis periods. While effects appear non-linear, they are not U-shaped, as households with the highest indebtedness respond most to monetary policy shocks. This suggests that household debt did not contribute to lessening the effects of monetary policy over time, since the distribution of debt did not change markedly with the crisis, while its average even increased somewhat. ${ }^{5}$

Similar results hold for household liquidity. Households with lower levels of liquid assets react more strongly to monetary policy shocks, both pre- and post-crisis. Again, because the distribution of liquidity across households remained stable over time, liquidity constraints cannot explain the decline in monetary policy effectiveness. The explanation for the lower effectiveness of monetary policy must therefore lie elsewhere, such as in the higher degree of economic uncertainty brought about by the crisis. We find tentative evidence in favor of this hypothesis.

\section{HypotheSES AND DATA}

The main questions we explore in this paper are:

(1) Has the response of household consumption to monetary policy shocks declined since the global financial crisis?

(2) Do households with greater indebtedness respond more strongly to monetary policy shocks? Is there evidence of nonlinearities_in particular does the responsiveness decline after a certain threshold?

(3) Do households with low levels of liquid assets react more to monetary policy shocks? And again, are non-linear effects discernable?

(4) Can shifts in the distribution of household indebtedness and liquidity between the pre- and post-crisis periods explain the observed changes in the average response of household consumption to monetary policy?

\footnotetext{
${ }^{4}$ Recent papers suggest that consumption responses to monetary policy should depend on the distribution of households' liquidity; see Heterogeneous Agent New Keynesian (HANK) models (such as Kaplan and others, 2018, Kaplan and Violante, 2018, Hedlund and others, 2016, and Francisco, 2018).

${ }^{5}$ Justiniano and others (2015) and Yellen (2016) also suggest that debt overhang alone cannot explain the slow recovery from the U.S. Great Recession. Also, Bernanke (2018) does not find strong predictive powers of household balance sheets for economic conditions, although he argues that it does not dismiss the important role of household balance sheets considering the empirical challenges in identifying macro effects.
} 


\section{A. Data: Variables of Interest, Sources, and Summary Statistics}

We use the Consumer Expenditure Survey $(\mathrm{CEX})^{6}$ for household-level consumption, income, and balance-sheet data between 1996Q1 and 2014Q4. The CEX data are well suited for our analysis for three reasons. First, the survey offers rich cross-sectional variation, with about 7,500 households interviewed per quarter. Second, the quarterly frequency is helpful to study the short-run effects of monetary policy on households' consumption. Third, CEX data span a sufficiently long period to compare household behavior before and after the crisis.

We construct measures of durable and non-durable consumption expenditures. This is to allow for the impact of monetary policy to differ across each category of goods since theory and empirics suggest that the marginal propensity to consume for durable and non-durable goods are significantly different (Souleles, 1999; Parker and others, 2013; see Appendix I for more details).

We consider two key characteristics of household balance sheets: indebtedness and liquidity. Indebtedness is defined as the ratio of each household's total mortgage balance (summed over all the properties owned by the household) to the value of the houses it owns, as reported by households. We exclude other liabilities like credit card balances, since fewer households report these and because mortgage debt is the most significant liability for most households. ${ }^{7}$ We define liquidity as the ratio of liquid assets to monthly income, as reported by households. Liquid assets include the total balance on households' checking and savings accounts, and income is after-tax. Details are provided in Appendix I.

Table 1 highlights key features of non-durable and durable consumption. On average, households spend four times more on non-durable consumption relative to durable consumption in any given quarter. However, the standard deviation of durable consumption is notably larger than that of non-durable consumption, pointing to the lumpy nature of durable goods purchases (Caballero, 1993). Consumption levels differ across housing tenure, especially for durable consumption (see Appendix 1). ${ }^{8}$ The distribution of consumption quarter-on-quarter growth changes little after the crisis for both durable and non-durable categories, while the distribution of consumption levels shifts slightly to the left after the crisis.

\footnotetext{
${ }^{6}$ CEX data available at: <https://www.bls.gov/cex/pumd_data.htm\#stata>

${ }^{7}$ The CEX collects mortgage information in all interviews, while it collects other financial information (such as credit card debt) only in the 2nd and 5th interviews. Therefore, we focus on mortgage debt, the largest component of household debt, in examining the effects of indebtedness.

${ }^{8}$ Housing tenure is a factor that has been found to be correlated with consumption decisions. See, for example Aladangady (2014) and Cloyne and others (2018).
} 
Table 1. Real Non-Durable and Durable Consumption

\begin{tabular}{|c|c|c|c|c|c|c|}
\hline & \multicolumn{3}{|c|}{ Percentiles } & \multirow{2}{*}{\multicolumn{2}{|c|}{$\begin{array}{l}\text { Std. } \\
\text { Dev. }\end{array}$}} & \multirow[b]{2}{*}{ Obs. } \\
\hline & 25th & 50th & 75th & & & \\
\hline \multicolumn{7}{|c|}{ Quarterly consumption, in 2000 Q1 (In U.S. dollars) } \\
\hline Non-durable & 2,358 & 3,598 & 5,404 & 4,320 & 2,894 & 354,685 \\
\hline Durable & 0 & 36 & 306 & 1,048 & 3,805 & 354,685 \\
\hline \multicolumn{7}{|c|}{ Growth rate (Q-on-Q) (In percent) } \\
\hline Non-durable & -18.2 & 0.0 & 18.3 & 0.0 & 33.1 & 265,712 \\
\hline Durable & -147.7 & -3.6 & 140.7 & -3.6 & 235.8 & 114,563 \\
\hline
\end{tabular}

Sources: CEX and IMF staff calculations.

Note: Consumption variables are in constant dollars $(2000 \mathrm{Q} 1=100)$ and winsorized at 1 percent of each tail.

Homeowners take on varying, though generally high, levels of debt (Table 2). ${ }^{9}$ On average, 74 percent of households own a house, of which almost two-thirds have mortgage debt (see Appendix 1). ${ }^{10}$ Average indebtedness among households over the entire sample is high, at nearly 60 percent, as is the standard deviation of consumption, at 42 percent. The distribution is skewed to the right, however, and does not change particularly from pre- to post-crisis, as discussed further in Section 4.

\section{Table 2. Household Indebtedness}

\begin{tabular}{ccccccccc}
\hline & & \multicolumn{3}{c}{ Leverage by Percentile } & & & \\
\cline { 3 - 6 } & $\begin{array}{c}\text { Share of } \\
\text { Underwater } \\
\text { (In percent) }\end{array}$ & 25th & 50th & 75th & Mean & Dev. & Obs. \\
\hline $\begin{array}{c}\text { Homeowners } \\
\text { W/ mortgage }\end{array}$ & 5.6 & 29.3 & 55.0 & 80.5 & 59.3 & 42.3 & 155,661 \\
\hline
\end{tabular}

Sources: CEX and IMF staff calculations.

Note: Indebtedness is defined as the ratio of mortgage debt to house values and it is winsorized at 1 percent of each tail. "Underwater" households are defined as those with a leverage ratio greater than one (i.e., a negative home equity).

Liquidity levels also vary significantly across households (Table 3). Median liquidity is lowest for renters, and highest for homeowners without mortgages. The same is true of standard deviations. The distribution is especially skewed towards lower liquidity levels due to "hand-to-mouth" households whose liquid assets are less than a half of their monthly income (Kaplan and others 2014). The share of such households is nearly 60 percent, of which about two thirds are homeowners which can thus be considered as "wealthy hand-to-

\footnotetext{
${ }^{9}$ As also found in Kaplan and others (2014) and Hedlund and others (2016).

${ }^{10}$ More than 80 percent of mortgage contracts in our sample are fixed rate mortgages.
} 
mouth” households. ${ }^{11}$ The distribution of liquidity does not change noticeably from pre- to post-crisis, either, as reviewed in Section 4.

Table 3. Household Liquidity

\begin{tabular}{|c|c|c|c|c|c|c|c|}
\hline & \multirow{2}{*}{$\begin{array}{l}\text { Share of Hand-to- } \\
\text { Mouth } \\
\text { (In percent) }\end{array}$} & \multicolumn{3}{|c|}{ Liquidity by Percentile } & \multirow[b]{2}{*}{ Mean } & \multirow{2}{*}{$\begin{array}{l}\text { Std. } \\
\text { Dev. }\end{array}$} & \multirow[b]{2}{*}{ Obs. } \\
\hline & & 25th & 50th & 75th & & & \\
\hline Homeowners & 41.2 & 1.0 & 6.2 & 26.0 & 51.1 & 148.3 & 175,391 \\
\hline w/ mortgage & 28.0 & 1.1 & 5.2 & 17.6 & 30.1 & 99.1 & 111,241 \\
\hline w/o mortgage & 13.2 & 0.8 & 10.0 & 57.1 & 87.6 & 202.6 & 64,150 \\
\hline Renters & 18.7 & 0.0 & 0.6 & 5.9 & 19.4 & 92.2 & 70,856 \\
\hline All & 59.9 & 0.2 & 4.0 & 18.8 & 42.0 & 135.4 & 246,247 \\
\hline
\end{tabular}

Sources: CEX and IMF staff calculations.

Note: Liquidity is defined as the ratio of liquid assets to monthly income, following Kaplan and others (2014) and it is winsorized at 1 percent of each tail. The "hand-to-mouth" households are defined as those whose liquid assets are less than a half of their monthly income, following Kaplan and others (2014).

\section{B. Identifying Monetary Policy Shocks}

As typical in this literature, we face a tradeoff between overcoming endogeneity and measuring a meaningful relationship between monetary policy and consumption. The former pushes us to seek exogenous monetary policy shocks. However, as these tend to be small, finding a stable and substantial effect on consumption can be difficult.

We identify monetary policy shocks using high frequency data at the time of monetary policy announcements. We do so in the tradition of Bernanke and Kuttner (2005), by capturing changes in asset prices closely correlated with monetary policy expectations. However, unlike Bernanke and Kuttner, we do not use futures on Federal Fund Rates, since these remained little changed (and close to zero) during the post-crisis period, despite repeated steps taken to loosen monetary policy, such as through quantitative easing (QE) programs.

To find a measure that is equally suitable for pre- and post-crisis periods, we resort to changes in 2-year bond yields, taking the cue from Gürkaynak, Sack, and Swanson (2005 and 2007), and subsequently, Gilchrist and others (2015), Ferrari and others (2017), and Hanson and Stein (2015), among others. The identifying assumption is that 2-year bond yields on the day prior to a scheduled monetary policy announcement capture market expectations of future policy interest rates, as well as perceptions of policy uncertainty as reflected in term premia. Thus, changes in 2-year yields on announcement days reflect the surprise component

\footnotetext{
${ }^{11}$ The share of hand-to-mouth households is likely overstated due to our narrow definition of liquid assets. Kaplan and others (2014) find the share to be 31 percent based on a broader definition of liquid assets allowed by granular balance-sheet data from the Survey of Consumer Finances for 1989-2010. However, the paper also finds the share of "wealthy hand-to-mouth" households to be around two-thirds, as in our sample.
} 
of monetary policy along both dimensions. We sum monetary policy surprises from all announcements in a given quarter, as in Romer and Romer (2004), to construct measures consistent with our quarterly data on consumption.

\section{Has the Response of Household Consumption Changed Post-Crisis?}

Households are only interviewed by the CEX survey for four consecutive quarters, and subsequently drop out of the dataset. This limits the assessment of consumption reaction to monetary shocks to a time horizon of three quarters. Therefore, for a first analysis of impulse responses to monetary shocks, we construct synthetic cohorts to obtain longer time series.

Constructing synthetic cohorts amounts to categorizing households at any given quarter according to pre-defined buckets, then linking the data between buckets to create longer time-series. The underlying assumption is that households with similar characteristicsbelonging to the same bucket—respond similarly to monetary policy shocks. Obviously, such an approach has its limitations, since households can differ along many characteristics which are not controlled for.

We build cohorts using the head of household's birth year and housing tenure. For the grouping by birth year we define 14 groups using 5-birth year intervals, while for the grouping by housing tenure we retain 3 groups: owners with mortgage, owners without mortgage, and renters. As a result, we build 42 representative consumer units with data for the whole sample period. More details on the construction of synthetic cohort panel data are provided in Appendix II.

We then use the panel of synthetic cohorts to estimate the response of durable- and nondurable consumption to monetary policy, estimating the impulse response function using Jordà’s (2005) local projection method:

$$
\begin{aligned}
& \ln \left(\frac{C_{j, t+h}}{C_{j, t-1}}\right)=\beta_{0}^{(h)}+\beta_{1}^{(h)} 2 y r_{t}+\beta_{2}^{(h)} \text { postGFC }+\beta_{3}^{(h)} \text { postGFC } * 2 y r_{t} \\
& +\beta_{4}^{(h)} X_{j, t}+\beta_{5}^{(h)} S_{t}+\epsilon_{j, t+h} \quad h=1, \ldots, 12
\end{aligned}
$$

where $\ln \left(\frac{c_{j, t+h}}{c_{j, t}}\right)$ is the cumulative log change in real consumption by the synthetic cohort $j$ between periods $t$ and $t+h, 2 y r_{t}$ is the 2-year yield, $X_{j, t}$ is a cohort-specific vector of controls that includes age and age squared, and $S_{t}$ is a set of macro controls that includes inflation, GDP growth rate, and quarterly dummies.

To test the hypothesis that the effect of monetary policy has changed after the GFC, we include a dummy variable, labeled postGFC in the above equation, for the post-crisis period (2009Q1 and onwards) and interact it with the policy rate. The coefficients $\beta_{1}^{(h)}$ captures the 
pre-GFC effect of monetary policy and $\beta_{3}^{(h)}$ captures the additional effect of monetary policy added in the post-GFC.

We instrument the 2-year yield ( $2 y r_{t}$ ) to address endogeneity - the possibility that bond yields reflect monetary policy responses to changes in consumption. As instruments, we adopt exogenous monetary policy shocks from high-frequency data, as discussed earlier. We exploit overidentification to overcome weak instrument bias by using the contemporaneous monetary policy shock and its lags as the instruments. We use the Generalized Method of Moments (GMM) to obtain more precise estimates. ${ }^{12}{ }^{13}$

Turning to the results, the pre-GFC effect of monetary policy measured by $\beta_{1}^{(h)}$ is negative on both durable and non-durable consumption growth, while the additional effect due to the post GFC $\beta_{3}^{(h)}$ is positive at most projection horizons (Figure 1).

These results suggest that the responsiveness of consumption to monetary policy has changed and has likely weakened since the crisis. However, the change seems difficult to measure in a precise and robust manner. The size and significance of $\beta_{3}^{(h)}$ varies as the specification of equation (1) is modified by, for example, changing the set of controls to include more lags. The message we therefore take from this exercise is that it offers suggestive, but not conclusive and precise evidence for a weakening of monetary policy effects on household consumption in the post-crisis period.

\footnotetext{
${ }^{12}$ See Ramey (2016) and Stock and Watson (2018).

${ }^{13}$ We also experimented using more than one type of monetary policy shock (as explained in appendix III). Results are robust to instrumenting the policy rate with the signal shock and the risk shock described above.
} 
Figure 1. Response of Durable and Non-Durable Consumption to Monetary Policy Direct Effect of Monetary Policy $\left(\boldsymbol{\beta}_{1}^{(h)}\right)$

Durable Consumption

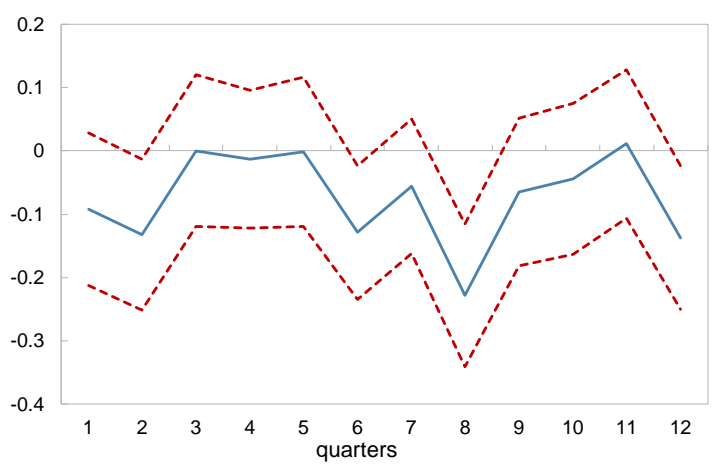

Non-Durable Consumption

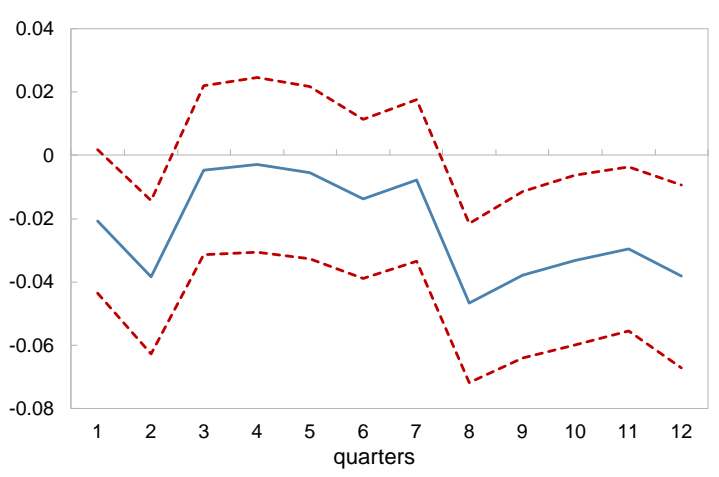

Marginal Effect of Monetary Policy Interacted with Post-GFC Dummy $\left(\beta_{3}^{(h)}\right)$

Durable Consumption

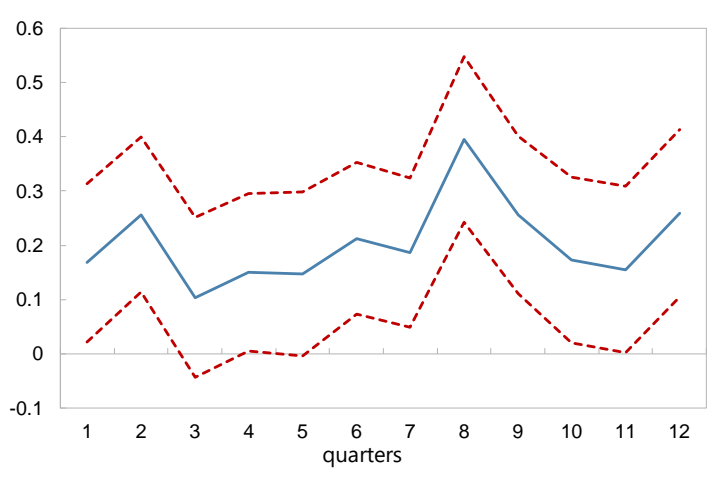

Non-Durable Consumption

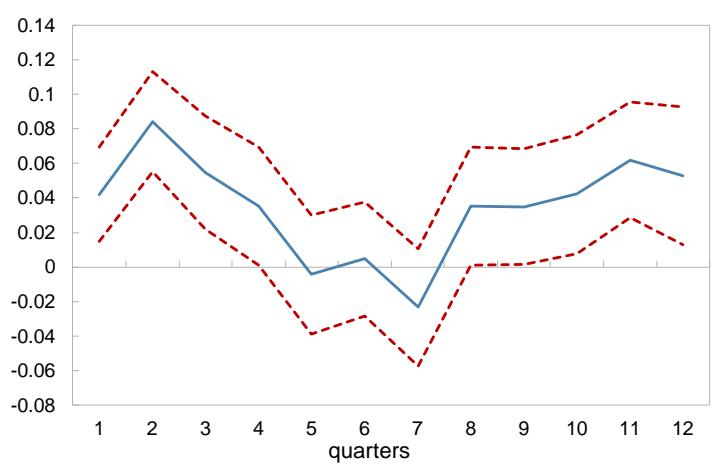

Source: IMF staff estimates.

Note: GMM estimation, 1996Q1-2014Q4. Dependent variable is the accumulated quarterly growth rate in real consumption. Individual data from CEX are aggregated in 42 synthetic cohorts according to housing status and 5-year birth year intervals. In the first stage regression, the 2-year yield is instrumented by monetary policy shocks (see Appendix III description of these shocks). All regressions include a constant, aggregate macroeconomic controls (inflation and real GDP growth), and quarterly seasonal effects. Standard errors are robust to heteroskedasticity and autocorrelation. Full line shows the estimated effect, while the dotted lines show the 90 percent confidence interval.

We thus tackle the same question using the full micro-data set, without aggregating households in cohorts-at the expense of only observing consumption growth for three consecutive quarters for any single household. We run the following regression:

$$
\begin{array}{r}
\ln \left(\frac{C_{i, t+1}}{C_{i, t-1}}\right)=\beta_{o}+\beta_{1} 2 y r_{t}+\beta_{2}\left(\text { postGFC } \cdot 2 y r_{t}\right)+\beta_{3} \text { postGFC } \\
+\mathrm{B} Z_{i, t}+\lambda_{s(t)}+u_{i, t}
\end{array}
$$

where $\ln \left(\frac{c_{i, t+1}}{c_{i, t-1}}\right)$ is the cumulative log change in real consumption for individual household $i$ (instead of a synthetic cohort as above). We focus on two-quarter growth rates in 
consumption to allow for lags in monetary policy transmission. ${ }^{14}$ postGFC again denotes a dummy variable that takes the value of one since 2009Q1, $\boldsymbol{Z}_{\boldsymbol{i}, \boldsymbol{t}}$ denotes household level controls, which include race, education level, age, family size, and marital status. $\lambda_{s(t)}$ stands for seasonal fixed effects. ${ }^{15}$

We follow the same procedure as before in instrumenting 2-year yields $\left(2 y r_{t}\right)$ using highfrequency monetary policy shocks and their lags as instruments to overcome weak instrument bias, and using GMM estimation.

The results confirm the earlier findings of a weaker impact of monetary policy after the crisis. Overall, we find the expected response of both durable and non-durable consumption to monetary policy shocks. In the pre-crisis period, an expansionary monetary policy shock (a 10-basis point reduction in the 2-year yield) increases non-durable and durable consumption by about 3 percent and 2 percent, respectively (Table 4, columns 3 and 4). In the post-crisis period, the response of durable- and non-durable consumption to monetary policy is clearly weaker (as seen by positive and significant values of $\beta_{2}$ ). For durable consumption, the effect is only marginally statistically significant (Table 4, columns 4 and 6). 16

Household-level controls have a significant and expected impact on households' non-durable consumption. College-educated, white, married, and older households display higher consumption growth following looser monetary policy. However, these characteristics are not found to be important determinants of durable consumption.

When we estimate equation (2) over the full sample, by removing the post-GFC dummy and its interaction with monetary policy, results show that expansionary monetary policy boosts both durable and non-durable consumption, as expected (Figure 2 and Table 4, column 1 and 2). The estimated effect is stronger for nondurables; a 10 basis-point increase in the 2-year yield reduces non-durable consumption by 2.5 percent and durable consumption by 0.5 percent. ${ }^{17}$ Results for durable consumption are in general less robust, partly reflecting the

\footnotetext{
${ }^{14}$ The rotating nature of data does not allow for a more dynamic analysis of consumption response to monetary policy, an issue we explore using synthetic cohorts. We use 2-quarter ahead consumption growth in the panel analysis to strike a balance between allowing for a transmission lag and not losing too many observations. The results are broadly robust to the choice of 1,2, or 3 quarters.

${ }^{15}$ See Table A.1 for correlations among consumption growth, household characteristics. and balance sheet variables. Households' balance sheet variables (liquidity and leverage) are not found to be highly correlated with household level characteristics (family size, education, ethnicity, marital status, etc.).

${ }^{16}$ Our main results are robust to adding income change as an additional control variable (table 4 (columns 5 and 6)).

${ }^{17}$ These results are not directly comparable to those in the literature because this full sample includes the postGFC period. Moreover, to our knowledge, our novel approach, which uses monetary policy shocks as instruments, has not been used in other studies with micro-level data; the literature tends to use monetary policy shocks as regressors (e.g., Wong 2014) or use other variables to instrument a change in a relevant interest rate
} 
diminished response of durables consumption to monetary policy shocks post-crisis, as shown above. ${ }^{18}$

\section{Table 4. Impact of Monetary Policy on Consumption: Has it Changed After the Crisis?}

\begin{tabular}{|c|c|c|c|c|c|c|}
\hline Variables & $\begin{array}{c}1) \\
\text { Non-durables } \\
\end{array}$ & $\begin{array}{c}(2) \\
\text { Durables } \\
\end{array}$ & $\begin{array}{c}(3) \\
\text { Non-Durables } \\
\end{array}$ & $\begin{array}{c}(4) \\
\text { Durables } \\
\end{array}$ & $\begin{array}{c}(5) \\
\text { Non-Durables } \\
\end{array}$ & $\begin{array}{c}6) \\
\text { Durables } \\
\end{array}$ \\
\hline 2-yr yield & $\begin{array}{c}-24.24^{\star \star \star} \\
(4.46)\end{array}$ & $\begin{array}{l}-4.37^{\star} \\
(2.27)\end{array}$ & $\begin{array}{c}-28.60^{\star \star \star} \\
(5.20)\end{array}$ & $\begin{array}{c}-17.81^{\star \star} \\
(8.57)\end{array}$ & $\begin{array}{c}-31.00^{* \star *} \\
(5.92)\end{array}$ & $\begin{array}{l}-16.55^{\star} \\
(8.76)\end{array}$ \\
\hline Family size & $\begin{array}{l}-0.13 \\
(0.08)\end{array}$ & $\begin{array}{l}0.06 \\
(0.74)\end{array}$ & $\begin{array}{l}-0.13 \\
(0.09)\end{array}$ & $\begin{array}{c}0.07 \\
(0.74)\end{array}$ & $\begin{array}{l}-0.17^{\star *} \\
(0.09)\end{array}$ & $\begin{array}{c}0.04 \\
(0.75)\end{array}$ \\
\hline College education & $\begin{array}{l}0.85^{\star \star \star} \\
(0.24)\end{array}$ & $\begin{array}{c}0.41 \\
(1.97)\end{array}$ & $\begin{array}{l}0.88^{\star \star \star} \\
(0.24)\end{array}$ & $\begin{array}{c}1.33 \\
(1.88)\end{array}$ & $\begin{array}{l}0.95^{\star \star \star} \\
(0.24)\end{array}$ & $\begin{array}{l}1.25 \\
(1.91)\end{array}$ \\
\hline White & $\begin{array}{l}0.74^{\star *} \\
(0.29)\end{array}$ & $\begin{array}{l}2.49 \\
(2.87)\end{array}$ & $\begin{array}{l}0.72^{\star \star} \\
(0.29)\end{array}$ & $\begin{array}{l}2.15 \\
(2.84)\end{array}$ & $\begin{array}{l}0.71 \text { ** } \\
(0.30)\end{array}$ & $\begin{array}{l}1.86 \\
(2.87)\end{array}$ \\
\hline Married & $\begin{array}{l}0.63^{* \star *} \\
(0.25)\end{array}$ & $\begin{array}{c}0.90 \\
(2.20)\end{array}$ & $\begin{array}{l}0.59 * * \\
(0.25)\end{array}$ & $\begin{array}{c}0.55 \\
(2.17)\end{array}$ & $\begin{array}{l}0.54^{\star *} \\
(0.25)\end{array}$ & $\begin{array}{c}0.53 \\
(2.20)\end{array}$ \\
\hline Reference age & $\begin{array}{l}0.02^{\star \star \star} \\
(0.01)\end{array}$ & $\begin{array}{c}0.05 \\
(0.07)\end{array}$ & $\begin{array}{l}0.02^{\star \star \star} \\
(0.01)\end{array}$ & $\begin{array}{c}0.08 \\
(0.07)\end{array}$ & $\begin{array}{l}0.02^{\star \star \star} \\
(0.01)\end{array}$ & $\begin{array}{l}0.07 \\
(0.07)\end{array}$ \\
\hline postGFC & & & $\begin{array}{l}-7.69^{* \star *} \\
(1.47)\end{array}$ & $\begin{array}{l}-0.22 \\
(5.56)\end{array}$ & $\begin{array}{c}-8.44^{\star \star \star} \\
(1.65)\end{array}$ & $\begin{array}{c}0.33 \\
(5.74)\end{array}$ \\
\hline postGFC*2-yr yield & & & $\begin{array}{l}3.31^{\star \star \star} \\
(0.92)\end{array}$ & $\begin{array}{l}11.60^{*} \\
(6.50)\end{array}$ & $\begin{array}{l}3.64^{\star \star \star} \\
(0.99)\end{array}$ & $\begin{array}{l}11.46^{*} \\
(6.79)\end{array}$ \\
\hline Income growth & & & & & $\begin{array}{l}0.04^{\star \star \star} \\
(0.00)\end{array}$ & $\begin{array}{l}0.08^{\star \star} \\
(0.03)\end{array}$ \\
\hline Observations & 166,921 & 69,781 & 166,921 & 69,781 & 161,449 & 68,008 \\
\hline
\end{tabular}

Source: IMF staff estimates.

Notes: GMM estimation, 1996Q1 - 2014Q4. Dependent variable is 2-quarter ahead consumption growth. In the first stage regression, 2-year yield is instrumented by monetary policy shocks (see Appendix III for description of monetary policy shock). All regressions include a constant, and quarter (seasonal) effects. Clustered standard errors (by households) are reported in parenthesis. ${ }^{\star \star \star},{ }^{\star \star}$, and * indicate statistical significance at the 1,5 , and 10 percent levels, respectively.

(e.g., Aladangady 2017). Further, while Wong (2014) estimates consumption elasticity to monetary policy shocks, we focus on the consumption response to exogenous changes in policy-relevant interest rates, allowing for making more meaningful and policy relevant conclusions.

${ }^{18}$ Another reason may be the lumpy nature of durables consumption, which implies lags in responses to monetary policy shocks. To partly account for potential lags, we use current and lagged monetary policy shocks as instruments for the 2-year yield when estimating equation 2 for durable consumption growth. 
Figure 2. Consumption Response to 10-Basis Point Increase in 2-Year Yield (In percentage points)

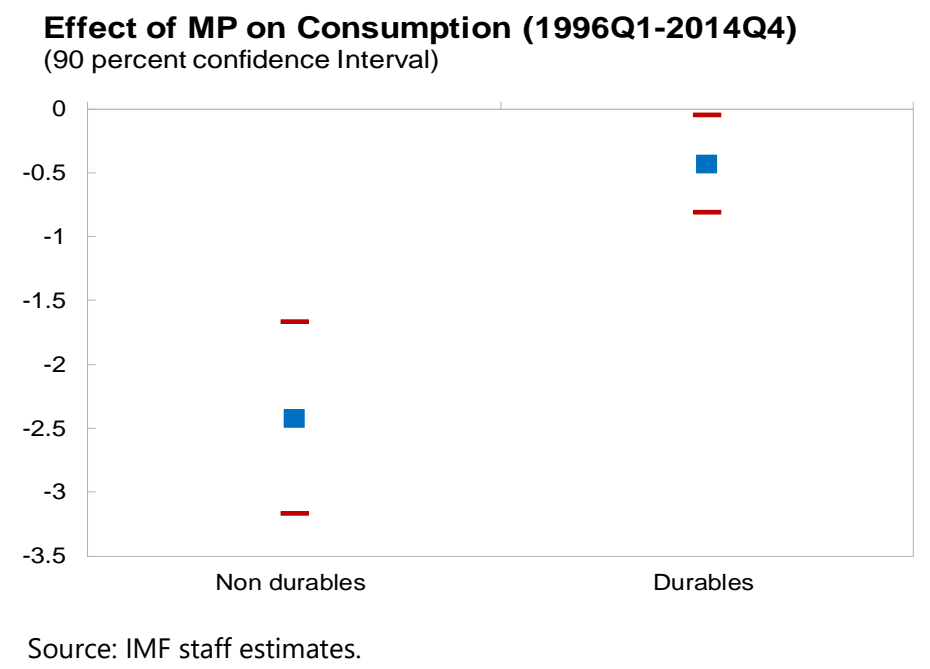

\section{DOES HOUSEHOLd INDEBTEDNESS MATTER?}

In this section we ask whether household indebtedness affects the response of consumption to monetary policy impulses. Next, we explore the role of non-linearities, and ask whether the change in the distribution of household indebtedness post-crisis might help explain the lower monetary policy impact on consumption detected earlier.

To tackle the first question, we estimate an equation of the form:

$$
\ln \left(\frac{C_{i, t+1}}{C_{i, t-1}}\right)=\beta_{o}+\beta_{1} 2 y r_{t}+\beta_{2}\left(L T V_{i, t-1} \cdot 2 y_{t}\right)+\beta_{3} L T V_{i, t-1}+\mathrm{B} \boldsymbol{Z}_{i, t}+\lambda_{s(t)}+u_{i, t}
$$

As earlier, the model is estimated using GMM, where the 2-year yield is instrumented by monetary policy shocks. A negative value of $\beta_{2}$ supports the hypothesis that households with higher indebtedness respond more to monetary policy shocks. However, the total effect of monetary policy loosening on consumption growth must be read from $\beta_{1}+\beta_{2} * L T V$.

The results show that $\beta_{2}$ has a negative sign, in line with the notion of a higher responsiveness of more indebted households. The estimated coefficient is, however, only significant for durable consumption. To understand further whether and how the responsiveness of consumption to monetary policy shocks varies with household indebtedness, we check for the joint significance of $\beta_{1}$ and $\beta_{2}$ along the spectrum of possible values for indebtedness (Figure 3). 
Table 5. Impact of Monetary Policy on Consumption: The Role of Indebtedness

\begin{tabular}{|c|c|c|c|c|c|c|}
\hline Variables & $\begin{array}{c}\text { (1) } \\
\text { Non-Durables }\end{array}$ & $\begin{array}{c}(2) \\
\text { Durables }\end{array}$ & $\begin{array}{c}\text { (3) } \\
\text { Non-Durables }\end{array}$ & $\begin{array}{c}\text { (4) } \\
\text { Durables }\end{array}$ & $\begin{array}{c}\text { (5) } \\
\text { Non-Durables } \\
\end{array}$ & $\begin{array}{c}(6) \\
\text { Durables }\end{array}$ \\
\hline 2-yr yield & $\begin{array}{c}-22.41^{\star \star \star} \\
(7.19)\end{array}$ & $\begin{array}{l}5.66 \\
(6.02)\end{array}$ & $\begin{array}{l}-8.73^{\star \star \star} \\
(2.81)\end{array}$ & $\begin{array}{l}-27.33 \\
(22.05)\end{array}$ & $\begin{array}{c}-18.93^{\star \star \star} \\
(4.30)\end{array}$ & $\begin{array}{l}-41.46^{\star} \\
(23.41)\end{array}$ \\
\hline Family size & $\begin{array}{l}-0.15 \\
(0.14)\end{array}$ & $\begin{array}{l}-0.16 \\
(1.02)\end{array}$ & $\begin{array}{l}-0.07 \\
(0.12)\end{array}$ & $\begin{array}{l}-0.23 \\
(1.01)\end{array}$ & $\begin{array}{l}-0.10 \\
(0.14)\end{array}$ & $\begin{array}{l}-1.36 \\
(1.21)\end{array}$ \\
\hline College education & $\begin{array}{l}0.77^{\star \star} \\
(0.35)\end{array}$ & $\begin{array}{c}0.81 \\
(2.71)\end{array}$ & $\begin{array}{l}0.97^{\star \star \star} \\
(0.32)\end{array}$ & $\begin{array}{l}1.87 \\
(2.55)\end{array}$ & $\begin{array}{l}0.90^{\star *} \\
(0.39)\end{array}$ & $\begin{array}{c}2.45 \\
(3.06)\end{array}$ \\
\hline White & $\begin{array}{l}0.89^{*} \\
(0.53)\end{array}$ & $\begin{array}{c}0.31 \\
(4.23)\end{array}$ & $\begin{array}{l}1.19^{\star \star \star} \\
(0.45)\end{array}$ & $\begin{array}{l}-0.63 \\
(4.17)\end{array}$ & $\begin{array}{c}0.72 \\
(0.56)\end{array}$ & $\begin{array}{l}-3.49 \\
(5.23)\end{array}$ \\
\hline Married & $\begin{array}{c}0.57 \\
(0.42)\end{array}$ & $\begin{array}{c}0.16 \\
(3.35)\end{array}$ & $\begin{array}{c}0.41 \\
(0.38)\end{array}$ & $\begin{array}{l}-1.26 \\
(3.28)\end{array}$ & $\begin{array}{c}0.39 \\
(0.48)\end{array}$ & $\begin{array}{l}-0.93 \\
(4.01)\end{array}$ \\
\hline Reference age & $\begin{array}{c}0.01 \\
(0.02)\end{array}$ & $\begin{array}{l}-0.15 \\
(0.14)\end{array}$ & $\begin{array}{l}0.03^{\star *} \\
(0.01)\end{array}$ & $\begin{array}{l}-0.10 \\
(0.11)\end{array}$ & $\begin{array}{c}0.03 \\
(0.02)\end{array}$ & $\begin{array}{l}-0.13 \\
(0.14)\end{array}$ \\
\hline LTV & $\begin{array}{l}29.48 \\
(28.66)\end{array}$ & $\begin{array}{l}69.79^{\star *} \\
(29.68)\end{array}$ & & & & \\
\hline LTV*2-yr yield & $\begin{array}{l}-10.67 \\
(10.11)\end{array}$ & $\begin{array}{l}-21.43^{\star *} \\
(10.04)\end{array}$ & & & & \\
\hline I. $(\mathrm{LTV}<0.9)$ & & & $\begin{array}{l}-6.69^{\star \star \star} \\
(1.78)\end{array}$ & $\begin{array}{c}-6.43 \\
(14.65)\end{array}$ & $\begin{array}{c}-40.22^{\star \star \star} \\
(8.66)\end{array}$ & $\begin{array}{l}-78.48 \\
(48.50)\end{array}$ \\
\hline I. $($ LTV $<0.9) \star 2-y r$ yield & & & $\begin{array}{l}2.44^{\star \star *} \\
(0.67)\end{array}$ & $\begin{array}{c}5.02 \\
(5.15)\end{array}$ & $\begin{array}{l}9.74^{\star \star \star} \\
(2.10)\end{array}$ & $\begin{array}{l}19.79^{*} \\
(11.31)\end{array}$ \\
\hline Observations & 73,184 & 36,866 & 73,307 & 37,225 & 51,272 & 26,713 \\
\hline No. of Households & 37,576 & 24,351 & 37,644 & 24,517 & 26,075 & 17,346 \\
\hline Sample & Full & Full & Full & Full & Pre-crisis & Pre-crisis \\
\hline
\end{tabular}




\section{Figure 3. Effect of Monetary Policy on Consumption Growth at Different LTV Levels}
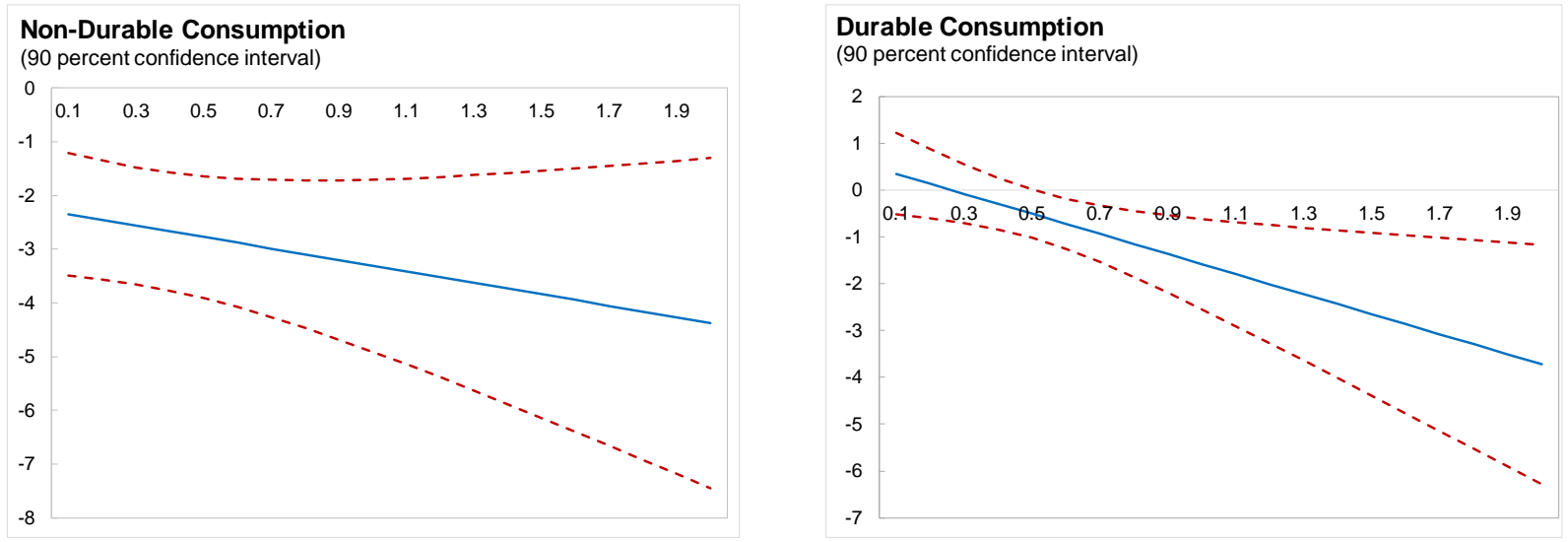

Source: IMF staff estimates.

Note: This graph shows the response of consumption to a 10-basis point increase in 2-year yield at different levels of household indebtedness. X-axis denotes LTV ratio and Y-axis is the consumption response measured by $\widehat{\beta_{1}}+\widehat{\beta_{2}} * L T V$ (based on equation 3), estimated at different LTV levels and corresponding 90 percent confidence intervals.

The confidence intervals widen at higher LTV levels. Furthermore, in the case of durable consumption, the overall impact of monetary policy is found to be significant only at LTV levels higher than 0.5 , suggesting that monetary policy may be effective only beyond a certain threshold. These results indicate that the response of consumption growth to monetary policy may potentially be non-linear.

As discussed earlier, looser monetary policy would be expected to strengthen balance sheets and reduce indebtedness by boosting house prices and reducing the net present value of mortgage payments. In turn, these effects should relax credit constraints and favor higher consumption. However, when indebtedness is especially high, the marginal improvement in balance sheets may not be sufficient to restore access to credit or allow for debt refinancing. We refer to this as the debt-overhang hypothesis. ${ }^{19}$

To study whether consumption growth responds non-linearly to household indebtedness, we estimate a threshold regression of the form:

$\ln \left(\frac{C_{i, t+1}}{C_{i, t-1}}\right)=\beta_{o}+\beta_{1} 2 y r_{t}+\beta_{2}\left(I_{L T V<0.9} \cdot 2 y r_{t}\right)+\beta_{3} I_{L T V<0.9}+B Z_{i, t}+\lambda_{s(t)}+u_{i, t}$

\footnotetext{
${ }^{19}$ Moreover, as discussed in Alpanda and Zubairy (2017) high levels of debt may dampen the effectiveness of monetary policy because "highly indebted households may be less willing, or less able, to borrow further in response to a rate cut, especially during recessionary periods when agents are facing higher job insecurity and income uncertainty." After a shock, households may need to rebuild wealth and increase precautionary savings (Mian and Sufi 2014, Carroll and Kimball 1996). A more specific channel refers to the mechanism by which under-the-water-households may not invest in their homes in response to a monetary easing (Melzer 2017).
} 
where $I_{L T V<0.9}$ is an indicator function that takes a value of 1 when indebtedness is less than the $90^{\text {th }}$ percentile over the sample period 1996Q1-2014Q4. Therefore, a significant value of $\beta_{2}$ implies that transmission is different across households with high and low indebtedness. We find that higher indebtedness increases responsiveness to monetary policy shocks for non-durable consumption over the full and pre-crisis samples (Table 5, columns 3 and 5, respectively). Thus, effects of indebtedness appear to be non-linear. The results for durable consumption are comparable over the pre-crisis sample (Table 5, column 6), and have the expected sign though are not significant for the full sample (Table 5, column 4).

We further explore the responsiveness of consumption at other thresholds, namely at 70, 80, 95, and 99th percentiles. Results corroborate the above findings: the response to monetary policy shocks increases with indebtedness, but there is no evidence that it diminishes above a very high threshold (Table 6). ${ }^{20}$ This is particularly evident for durable consumption which shows a monotonically increasing coefficient on indebtedness as the threshold is raised.

\title{
Table 6. Response of Consumption Growth to a 10-Basis-Point Increase in the 2-Year-Yield at Different LTV Thresholds ${ }^{1}$
}

\author{
(In percentage points)
}

\begin{tabular}{|c|c|c|c|c|c|c|c|c|}
\hline & LTV $<70$ & LTV $>70$ & LTV $<80$ & LTV $>80$ & LTV $<95$ & LTV > 95 & LTV $<99$ & LTV $>99$ \\
\hline & \multicolumn{8}{|c|}{ Full - sample } \\
\hline Non-durables & $\begin{array}{l}-0.63^{\star \star \star} \\
(0.004)\end{array}$ & $\begin{array}{l}-0.72^{\star \star \star} \\
(0.002)\end{array}$ & $\begin{array}{l}-0.63^{\star \star \star} \\
(0.004)\end{array}$ & $\begin{array}{l}-0.76^{\star \star \star} \\
(0.002)\end{array}$ & $\begin{array}{l}-0.63^{\star \star \star} \\
(0.004)\end{array}$ & $\begin{array}{l}-1.09 * \star \star \\
(0.002)\end{array}$ & $\begin{array}{l}-0.64^{\star \star \star} \\
(0.004)\end{array}$ & $\begin{array}{l}-2.03^{\star \star \star} \\
(0.001)\end{array}$ \\
\hline \multirow[t]{2}{*}{ Durables } & $\begin{array}{c}-2.19 \\
(0.201)\end{array}$ & $\begin{array}{c}-2.35 \\
(0.203)\end{array}$ & $\begin{array}{c}-2.22 \\
(0.198)\end{array}$ & $\begin{array}{c}-2.55 \\
(0.185)\end{array}$ & $\begin{array}{c}-2.24 \\
(0.193)\end{array}$ & $\begin{array}{c}-3.49 \\
(0.204)\end{array}$ & $\begin{array}{c}-2.25 \\
(0.202)\end{array}$ & $\begin{array}{l}-6.55 \\
(0.21)\end{array}$ \\
\hline & \multicolumn{8}{|c|}{ Pre - crisis } \\
\hline Non-durables & $\begin{array}{l}-0.91^{\star \star *} \\
(0.000)\end{array}$ & $\begin{array}{l}-1.19^{\star \star \star} \\
(0.000)\end{array}$ & $\begin{array}{l}-0.92^{\star \star \star} \\
(0.000)\end{array}$ & $\begin{array}{l}-1.30 \star \star \star \\
(0.000)\end{array}$ & $\begin{array}{l}-0.94^{\star \star \star} \\
(0.000)\end{array}$ & $\begin{array}{l}-2.99 * \star \star \\
(0.000)\end{array}$ & $\begin{array}{l}-0.93^{\star \star \star} \\
(0.000)\end{array}$ & $\begin{array}{l}-6.64^{\star \star \star} \\
(0.000)\end{array}$ \\
\hline Durables & $\begin{array}{c}-2.21^{*} \\
(0.085)\end{array}$ & $\begin{array}{c}-2.50 \\
(0.102)\end{array}$ & $\begin{array}{c}-2.19^{*} \\
(0.087)\end{array}$ & $\begin{array}{c}-2.93^{\star} \\
(0.083)\end{array}$ & $\begin{array}{c}-2.14^{*} \\
(0.085)\end{array}$ & $\begin{array}{c}-6.77^{\star} \\
(0.052)\end{array}$ & $\begin{array}{l}-2.14 \\
(0.1)\end{array}$ & $\begin{array}{c}-15.67^{\star} \\
(0.05)\end{array}$ \\
\hline
\end{tabular}

Source: IMF staff estimates

1/ Figures in parenthesis are P-values.

In summary, our results suggest that more indebted households respond more to monetary policy impulses. However, we do not find evidence of a debt overhang effect - that is, of a weakened response at very high levels of indebtedness.

\footnotetext{
20 The results are robust to alternative specifications. For example, in a quadratic specification responsiveness of consumption to monetary policy shocks is found to increase non-linearly with leverage.
} 
Thus, for indebtedness to explain the decrease in the average response of household consumption to monetary policy shocks, the overall distribution of indebtedness must have shifted leftward post-crisis, toward less indebted households. However, if anything, the distribution of indebtedness shifted to the right, though its mean decreased somewhat, as shown in Figure 4. Using estimated coefficients from equation 3 (Figure 3), the responsiveness of non-durable and durable

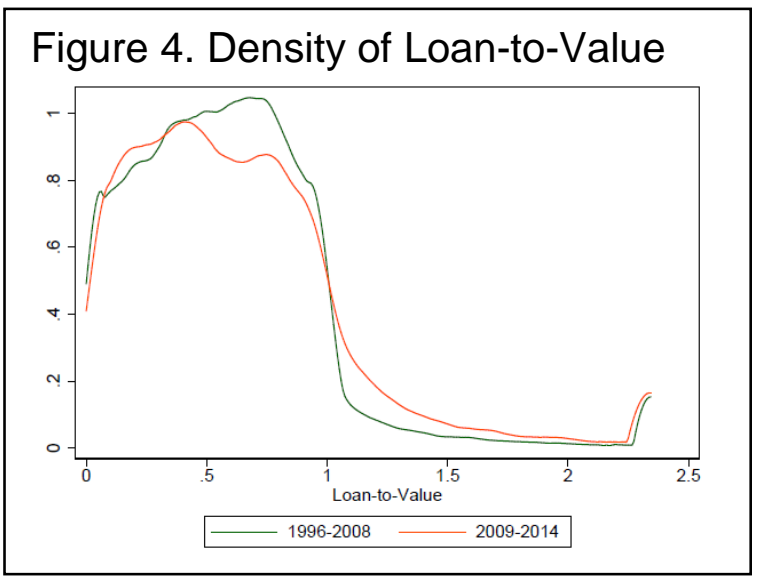
consumption to a 10-basis-point rise in the 2-year yield is found to increase by 2 and 4 basis points, respectively, due to shift in the distribution of household indebtedness post-crisis. The proportion of households in the top 10 percentile of LTV distribution grew from 5 percent before crisis to 8 percent in the post-crisis period. According to equation 4, this implies a 3and 6-basis-point increase in the responsiveness of non-durable and durable consumption, respectively, to a 10-basis-point hike in the 2-year yield. Thus, both specifications indicate that changes in the LTV distribution have per se contributed to a higher responsiveness of consumption to monetary policy in the post-crisis period. We must therefore look elsewhere to seek a plausible explanation for the drop in monetary policy effectiveness relative to consumption.

\section{DoEs Household Liquidity MATTER?}

We proceed in much the same way as in the earlier section. We ask whether the liquidity position of households affects their consumption response to monetary policy impulses. We further ask whether there are non-linearities, and whether the change in the distribution of household liquidity post-crisis might help explain the lower monetary policy impact on consumption detected earlier in this paper.

We begin by estimating the following equation:

$$
\ln \left(\frac{C_{i, t+1}}{C_{i, t-1}}\right)=\beta_{o}+\beta_{1} 2 y r_{t}+\beta_{2}\left(L I Q_{t-1} \cdot 2 y r_{t}\right)+\beta_{3} L I Q_{t-1}+\mathrm{B} Z_{i, t}+\lambda_{s(t)}+u_{i, t}
$$

In this specification, a positive value of $\beta_{2}$ supports the hypothesis that households with low liquidity respond more to monetary policy shocks.

Estimates of $\beta_{2}$ are however found to be insignificant (Table 7, columns 1 and 2). To investigate the issue further, we examine whether the responsiveness of consumption to monetary policy shocks varies with liquidity levels. For this purpose, we check for the joint significance of $\beta_{1}$ and $\beta_{2}$ along the spectrum of liquidity values (Figure 5). The results show 
that the responsiveness of non-durable consumption is only significant at relatively low liquidity values (with liquid-assets-to-monthly income ratios of up to around one).

We explore the possibility that only households with liquidity below a certain threshold respond more to interest rate shocks in a nonlinear setting. Specifically, we consider the following threshold regressions:

$$
\ln \left(\frac{C_{i, t+1}}{C_{i, t-1}}\right)=\beta_{o}+\beta_{1} 2 y r_{t}+\beta_{2}\left(I_{L I Q>.25} \cdot 2 y r_{t}\right)+\beta_{3} I_{L I Q>.25}+\mathrm{B} Z_{i, t}+\lambda_{s(t)}+u_{i, t}
$$

where $I_{L I Q>.25}$ is an indicator function that takes a value of 1 when a household's liquidassets-to-income-ratio is greater than the $25^{\text {th }}$ percentile over the sample period $1996 \mathrm{Q} 1-$ 2014 Q4.

The results indicate that non-durable consumption responds most strongly when households are liquidity constrained. We find qualitatively similar, but not statistically significant results for durable consumption (Table 7, column 3 and 4). ${ }^{21}$ Table 8 offers an interpretation of results, listing the extent of the consumption response to a 10-basis point surprise hike in the 2-year interest rate. The response of non-durable consumption increases monotonically as liquidity is lowered from the $20^{\text {th }}$ to the $10^{\text {th }}$ and $5^{\text {th }}$ percentiles. In the first case, consumption of non-durables rises by 2.3 percentage points, while in the last it increases by 2.5 percentage points-not an innocuous difference.

Overall, our results provide some support for the findings of Kaplan and Violante (2014) that non-durable consumption of wealthy hand-to-mouth households (namely those with limited liquid assets) responds more strongly to interest rate changes.

\footnotetext{
${ }^{21}$ As in the case of leverage, we also estimated equation 6 for durable consumption for the pre-crisis period. Liquidity continues to not matter for transmission of monetary policy to durable consumption even in the precrisis period.
} 
Table 7. Impact of Monetary Policy on Consumption: The Role of Liquidity

\begin{tabular}{|c|c|c|c|c|c|c|}
\hline Variables & $\begin{array}{c}(1) \\
\text { Non-durables } \\
\end{array}$ & $\begin{array}{c}(2) \\
\text { Durables } \\
\end{array}$ & $\begin{array}{c}(3) \\
\text { Non-Durables } \\
\end{array}$ & $\begin{array}{c}4) \\
\text { Durables } \\
\end{array}$ & $\begin{array}{c}5) \\
\text { Non-Durables } \\
\end{array}$ & $\begin{array}{c}6) \\
\text { Durables } \\
\end{array}$ \\
\hline 2-yr yield & $\begin{array}{l}-25.58^{\star \star} \\
(10.39)\end{array}$ & $\begin{array}{l}-1.65 \\
(6.12)\end{array}$ & $\begin{array}{c}-23.41^{\star \star \star} \\
(8.58)\end{array}$ & $\begin{array}{l}-14.98 \\
(18.26)\end{array}$ & $\begin{array}{c}-24.92^{\star \star \star} \\
(9.27)\end{array}$ & $\begin{array}{l}-18.62 \\
(21.55)\end{array}$ \\
\hline Family size & $\begin{array}{l}-0.12 \\
(0.16)\end{array}$ & $\begin{array}{l}-0.84 \\
(1.36)\end{array}$ & $\begin{array}{c}0.01 \\
(0.14)\end{array}$ & $\begin{array}{c}0.16 \\
(1.15)\end{array}$ & $\begin{array}{l}-0.06 \\
(0.14)\end{array}$ & $\begin{array}{l}-0.18 \\
(1.15)\end{array}$ \\
\hline College education & $\begin{array}{l}1.56^{* *} \\
(0.73)\end{array}$ & $\begin{array}{c}4.16 \\
(3.48)\end{array}$ & $\begin{array}{l}0.88^{* *} \\
(0.38)\end{array}$ & $\begin{array}{c}3.21 \\
(2.92)\end{array}$ & $\begin{array}{l}1.08^{\star \star \star} \\
(0.38)\end{array}$ & $\begin{array}{c}4.17 \\
(2.90)\end{array}$ \\
\hline White & $\begin{array}{c}0.80 \\
(0.89)\end{array}$ & $\begin{array}{l}-1.99 \\
(5.98)\end{array}$ & $\begin{array}{c}0.90 \\
(0.55)\end{array}$ & $\begin{array}{c}1.11 \\
(4.84)\end{array}$ & $\begin{array}{c}0.91 \\
(0.56)\end{array}$ & $\begin{array}{c}1.61 \\
(4.84)\end{array}$ \\
\hline Married & $\begin{array}{c}0.56 \\
(0.55)\end{array}$ & $\begin{array}{l}-1.32 \\
(4.45)\end{array}$ & $\begin{array}{c}0.46 \\
(0.45)\end{array}$ & $\begin{array}{l}-1.19 \\
(3.69)\end{array}$ & $\begin{array}{c}0.54 \\
(0.46)\end{array}$ & $\begin{array}{l}-0.45 \\
(3.70)\end{array}$ \\
\hline Reference age & $\begin{array}{c}0.03 \\
(0.02)\end{array}$ & $\begin{array}{l}-0.17 \\
(0.16)\end{array}$ & $\begin{array}{l}0.02^{*} \\
(0.01)\end{array}$ & $\begin{array}{c}-0.12 \\
(0.13)\end{array}$ & $\begin{array}{l}0.03^{*} \\
(0.02)\end{array}$ & $\begin{array}{c}-0.12 \\
(0.13)\end{array}$ \\
\hline Liquid assets/Income & $\begin{array}{l}-23.82 \\
(35.52)\end{array}$ & $\begin{array}{l}-1.85 \\
(14.13)\end{array}$ & & & & \\
\hline Liq ${ }^{\star 2}-y r$ yield & $\begin{array}{c}7.39 \\
(10.56)\end{array}$ & $\begin{array}{c}0.99 \\
(3.15)\end{array}$ & & & & \\
\hline I. (liq $>0.25)$ & & & $\begin{array}{l}-4.00^{*} \\
(2.25)\end{array}$ & $\begin{array}{c}4.28 \\
(9.04)\end{array}$ & & \\
\hline I. $(\operatorname{liq}>0.25)^{\star} 2-y r$ yield & & & $\begin{array}{l}2.27^{* \star *} \\
(0.75)\end{array}$ & $\begin{array}{c}1.21 \\
(2.61)\end{array}$ & & \\
\hline I. $(\operatorname{liq}>0.10)$ & & & & & $\begin{array}{l}-9.16^{\star *} \\
(4.55)\end{array}$ & $\begin{array}{l}-18.45 \\
(19.10)\end{array}$ \\
\hline I. $(\operatorname{liq}>0.10)^{\star} 2-y r$ yield & & & & & $\begin{array}{l}3.93^{\star \star \star} \\
(1.51)\end{array}$ & $\begin{array}{c}5.36 \\
(5.81)\end{array}$ \\
\hline Observations & 52,344 & 20,874 & 52,345 & 28,892 & 52,345 & 28,892 \\
\hline No. of Households & 26,885 & 18,820 & 26,885 & 18,821 & 26,885 & 18,821 \\
\hline
\end{tabular}

Source: IMF staff estimates.

Notes: GMM estimation, 1996Q1 - 2014Q4. Dependent variable is 2-quarter ahead consumption growth. In the first stage regression, 2year yield is instrumented by monetary policy shocks (see appendix III for description of monetary policy shock). All regressions include a constant, and quarter (seasonal) effects. Clustered standard errors (by households) are reported in parenthesis. ${ }^{* \star},{ }^{\star *}$, and * indicate statistical significance at the 1,5 and 10 percent levels, respectively. 
Figure 5. Effect of Monetary Policy on Consumption Growth at Different Liquidity Levels
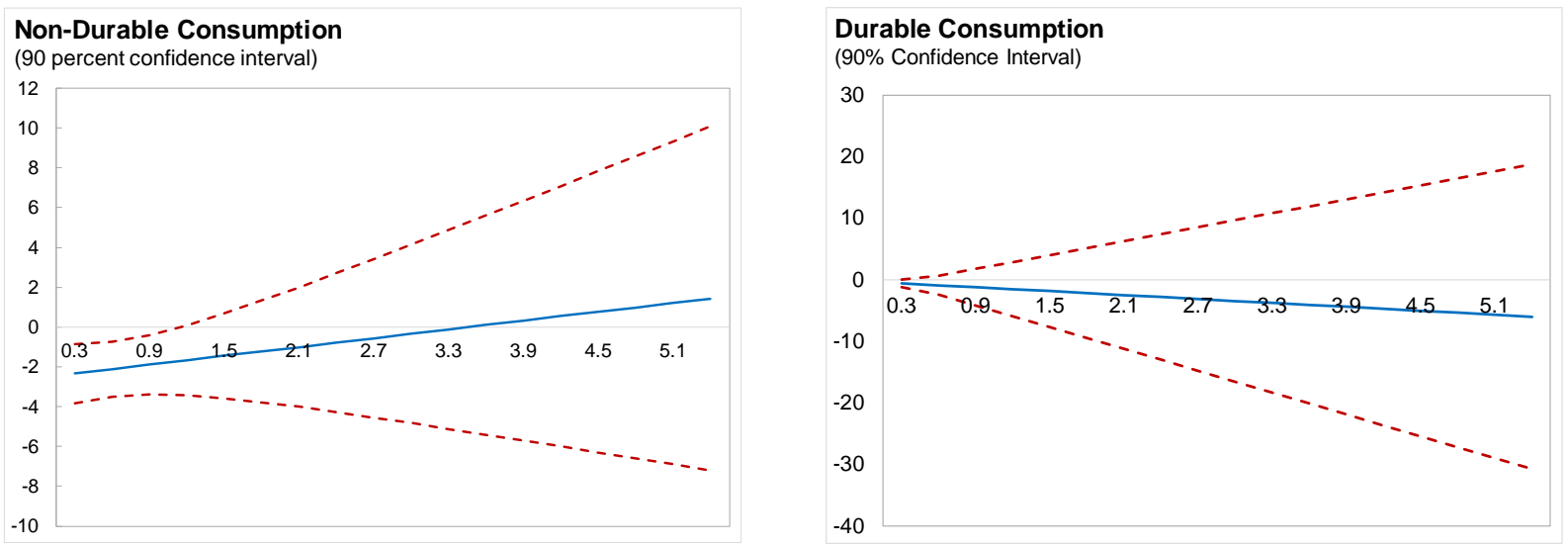

Source: IMF staff estimates.

Note: This graph shows the response of consumption to a 10-basis point increase in 2-year yield at different levels of household liquidity. $\mathrm{X}$-axis denotes liquid-assets-to-income ratio and $\mathrm{Y}$-axis is the consumption response, measured by $\widehat{\left(\widehat{\beta_{1}}\right.}+\widehat{\beta_{2}} *$ LIQ (based on equation 5), estimated at different liquidity levels and corresponding 90 percent confidence intervals.

\section{Table 8. Response of Consumption Growth to a 10 Basis Point Increase in the 2-Year Yield at Different Liquid-Asset-to-Income Thresholds ${ }^{1}$}

(In percentage points)

\begin{tabular}{ccccccccc} 
& $\mathrm{LIQ}<25$ & $\mathrm{LIQ}>25$ & $\mathrm{LIQ}<20$ & $\mathrm{LIQ}>20$ & $\mathrm{LIQ}<10$ & $\mathrm{LIQ}>10$ & $\mathrm{LIQ}<5$ & $\mathrm{LIQ}>5$ \\
\hline \hline Non-durables & $-2.34^{\star \star \star}$ & $-2.11^{\star \star \star}$ & $-2.39^{\star \star \star}$ & $-2.11^{\star \star \star}$ & $-2.49^{\star \star \star}$ & $-2.10^{\star \star \star}$ & $-2.49^{\star \star *}$ & $-2.10^{\star \star \star}$ \\
& $(0.006)$ & $(0.007)$ & $(0.006)$ & $(0.007)$ & $(0.007)$ & $(0.007)$ & $(0.007)$ & $(0.007)$ \\
Durables & -1.50 & -1.38 & -1.72 & -1.36 & -1.86 & -1.33 & -1.86 & -1.33 \\
& $(0.412)$ & $(0.399)$ & $(0.364)$ & $(0.408)$ & $(0.387)$ & $(0.419)$ & $(0.387)$ & $(0.419)$ \\
\hline
\end{tabular}

Source: IMF staff estimates

1/ Figures in parenthesis are P-values.

Lastly, we ask whether the change in the distribution of liquidity from pre- to postcrisis times might help explain the decline in monetary policy effects on consumption. For liquidity to be relevant, the distribution should have moved rightward, toward a lower share of liquidity constrained and highly responsive households.

However, the distribution of liquidity has hardly changed over time, or, if anything, has shifted to the left (Figure 6). Based on

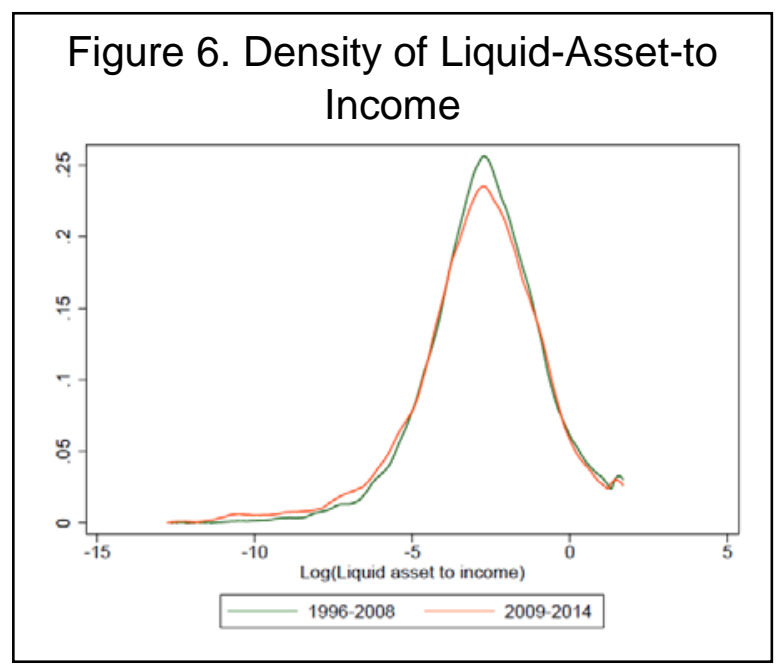
coefficient estimates from equation 5 , the responsiveness of non-durable consumption is 
found to marginally strengthen after the crisis due to the observed shift in the liquidity distribution (a 10-basis-point increase in 2-year yields leads to an additional 0.1-basis-point decline in non-durable consumption in the post-crisis period).

The share of households in the lower $25^{\text {th }}$ percentile of liquidity distribution rose from 24 percent pre-crisis to 28 percent after the crisis, which according to the estimates from equation 6 should also strengthen the responsiveness of non-durable consumption by 0.1 basis point (to a 10-basis-point increase in 2-year yield).

Hence, liquidity cannot explain the weakened response of consumption observed after the crisis either. The widespread concern that a deterioration of household balance sheets after the crisis hampered monetary policy effectiveness thus does not seem to hold.

What other factors may be responsible for the observed decline in monetary policy transmission to consumption? Aastveit, Natvik, and Sola (2017) report that U.S. monetary policy shocks affect economic activity less when uncertainty is high, in line with "realoption" effects from theory. We tentatively explore this hypothesis by interacting monetary policy shocks in our estimation with the index of economic policy uncertainty (denoted below by Unc) developed by Baker, Bloom, and Davis (2016):

$$
\ln \left(\frac{C_{i, t+1}}{C_{i, t-1}}\right)=\beta_{o}+\beta_{1} 2 y r_{t}+\beta_{2}\left(U n c_{t} \cdot 2 y r_{t}\right)+\beta_{3} U n c_{t}+\mathrm{B} Z_{i, t}+\lambda_{s(t)}+u_{i, t}
$$

Transmission to household consumption is indeed found to be stronger when economic policy uncertainty is low, at least for nondurables (Table 9). Figure 11 compares the strength of monetary policy transmission in periods of high uncertainty (above the $90^{\text {th }}$ percentile over the period 1996Q1-2014Q4) versus low uncertainty (below the $10^{\text {th }}$ percentile over the same period). While results hold qualitatively for non-durable and durable consumption, they are only significant for the former.

Using the estimates obtained from equation (7) and mean uncertainty levels for the pre- and post-crisis periods, we can attempt to explain the weaker transmission noted earlier postcrisis. The effects are quantitatively modest, with higher uncertainty explaining about one fourth and one fifth of the reduction in non-durable and durable consumptions' responsiveness to monetary policy, respectively. While this preliminary investigation provides only suggestive evidence, further research on this issue seems worthwhile. 


\section{Table 9. Impact of Monetary Policy on Consumption: The Role of Uncertainty}

\begin{tabular}{|c|c|c|}
\hline Variables & $\begin{array}{c}(1) \\
\text { Non-Durables }\end{array}$ & $\begin{array}{c}(2) \\
\text { Durables }\end{array}$ \\
\hline 2-yr yield & $\begin{array}{c}-13.77^{\star \star \star} \\
(2.70)\end{array}$ & $\begin{array}{l}-17.51 \\
(12.81)\end{array}$ \\
\hline Uncertainty*2-yr yield & $\begin{array}{l}0.01^{\star \star \star} \\
(0.00)\end{array}$ & $\begin{array}{c}0.04 \\
(0.03)\end{array}$ \\
\hline Uncertainty index & $\begin{array}{l}-0.14^{\star \star *} \\
(0.03)\end{array}$ & $\begin{array}{l}-0.08 \\
(0.11)\end{array}$ \\
\hline Family size & $\begin{array}{l}-0.12 \\
(0.08)\end{array}$ & $\begin{array}{c}0.05 \\
(0.74)\end{array}$ \\
\hline College education & $\begin{array}{l}0.92^{\star \star \star} \\
(0.24)\end{array}$ & $\begin{array}{c}1.22 \\
(1.88)\end{array}$ \\
\hline White & $\begin{array}{l}0.69 * \star \\
(0.29)\end{array}$ & $\begin{array}{c}2.15 \\
(2.84)\end{array}$ \\
\hline Married & $\begin{array}{l}0.55^{\star \star} \\
(0.24)\end{array}$ & $\begin{array}{c}0.57 \\
(2.17)\end{array}$ \\
\hline Reference age & $\begin{array}{l}0.02^{\star \star \star} \\
(0.01)\end{array}$ & $\begin{array}{c}0.08 \\
(0.07)\end{array}$ \\
\hline $\begin{array}{l}\text { Observations } \\
\text { No. of Households }\end{array}$ & $\begin{array}{c}166,921 \\
85,246\end{array}$ & $\begin{array}{l}69,781 \\
47,356\end{array}$ \\
\hline \multicolumn{3}{|c|}{$\begin{array}{l}\text { Notes: GMM estimation, 1996Q1 - 2014Q4. Dependent variable is 2- } \\
\text { quarter ahead consumption growth. In the first stage regression, 2- } \\
\text { year yield is instrumented by monetary policy shocks (see appendix } \\
\text { III for description of monetary policy shock). All regressions include a } \\
\text { constant, and quarter (seasonal) effects. Clustered standard errors } \\
\text { (by households) are reported in parenthesis. }{ }^{* * *} \text {, }{ }^{* *} \text {, and }{ }^{*} \text { indicate } \\
\text { statistical significance at the } 1,5 \text { and } 10 \text { percent levels, respectively. }\end{array}$} \\
\hline
\end{tabular}

\section{CONCLUSION}

We find that the average responsiveness of U.S. household consumption to well-identified monetary policy shocks has declined since the global financial crisis. However, this result cannot be explained by higher indebtedness or lower liquidity levels. Households with higher debt levels and lower shares of liquid assets are the most responsive to monetary policy, and the share of these households in the population grew. The common notion that a deterioration of household balance sheets after the crisis hampered monetary policy effectiveness is not validated in the data.

Nevertheless, household balance sheets do matter for the strength of monetary policy transmission, and our results underscore the notion that monetary policy makers need to pay close attention to them. Moreover, given the presence of nonlinearities (the responsiveness of more indebted households rises non-linearly with indebtedness), monitoring the distribution of household balance sheet characteristics is important. 
Although a full investigation of the issue is beyond the scope of this paper, we tentatively explored the role that higher economic uncertainty may have played in explaining the diminished responsiveness of household consumption to monetary policy. Preliminary evidence supports the notion that uncertainty may indeed have been an important factor, but more research on the issue is warranted. 


\section{REFERENCES}

Aastveit, Knut Are; Gisle James Natvik, and Sergio Sola, 2017, "Economic Uncertainty and the Influence of Monetary Policy,” Journal of International Money and Finance, Vol. 76, 50-67.

Aladangady, Aditya, 2014, “Homeowner Balance Sheets and Monetary Policy,” Finance and Economics Discussion Series 2014-98. Board of Governors of the Federal Reserve System (U.S.).

Aladangady, Aditya, 2017, “Housing Wealth and Consumption: Evidence from Geographically-Linked Microdata,” American Economic Review, 107 (11): 3415-46.

Alpanda, Sami, and Sara Zubairy, 2017, "Household Debt Overhang and Transmission of Monetary Policy,” unpublished manuscript, University of Central Florida.

Alter, Adrian, Alan Xiaochen Feng, and Nico Valckx, 2018, "Understanding the macrofinancial effects of household debt: a global perspective,” IMF Working Paper 18/76. International Monetary Fund, Washington, DC.

Attanasio, O. P., and S. Davis, 1996, "Relative Wage Movements and the Distribution of Consumption,” Journal of Political Economy, Vol. 104 (6): 1227-1262.

Baker, Scott R., Nicholas Bloom, and Steven J. Davis, 2016, "Measuring Economic Policy Uncertainty," The Quarterly Journal of Economics, Oxford University Press, Vol. 131(4), 1593-1636.

Bernanke, Ben S., 2018, “The Real Effects of the Financial Crisis” Brookings Papers on Economic Activity, BPEA Conference Drafts, September 13-14, 2018.

Bernanke, Ben S., and Kenneth N. Kuttner, 2005, "What Explains the Stock Market's Reaction to Federal Reserve Policy?" Journal of Finance 60(3), 1221-1257.

Caballero, Ricardo J., and Adam B. Jaffe, 1993, “How high are the giants’ shoulders: An empirical assessment of knowledge spillovers and creative destruction in a model of economic growth,” NBER Macroeconomics Annual 8:15-76.

Carroll, Christopher D., and Miles S. Kimball, 1996, "On the Concavity of the Consumption Function,” Econometrica, Vol. 64, No. 4, 981-992.

Cloyne, James, Clodomiro Ferreira, and Paolo Surico, 2018, "Monetary Policy when Households have Debt: New Evidence on the Transmission Mechanism,” Documentos de Trabajo No. 1813, Bank of Spain. 
Di Maggio, Marco, Amir Kermani, Benjamin J. Keys, Tomasz Piskorski, Rodney Ramcharan, Amit Seru, and Vincent Yao, 2017, "Interest Rate Pass-Through: Mortgage Rates, Household Consumption, and Voluntary Deleveraging,” American Economic Review, 107 (11):3550-88.

Drehmann, Mathias, Mikael Juselius, and Anton Korinek, 2017, "Accounting for Debt service: The Painful Legacy of Credit Booms", BIS Working Paper No. 645.

Dynan, Karen, 2012, “Is a Household Debt Overhang Holding Back Consumption?” Brookings Papers on Economic Activity, Spring 2012, 299-362,

Eggertsson, Gauti B., and Paul Krugman. 2012. "Debt, Deleveraging, and the Liquidity Trap: A Fisher-Minsky-Koo Approach.” Quarterly Journal of Economics, 127(3): 1469-1513.

Eggertsson, Gauti B., Neil R. Mehrotra, and Jacob A. Robbins, 2017, “A Model of Secular Stagnation: Theory and Quantitative Evaluation.” NBER Working Paper 23093.

Ferrari, M., J. Kearns, and A. Schrimpf, 2017, "Monetary policy's rising FX impact in the era of ultra-low rates”, BIS Working Paper No. 626.

Flodén, Martin, Matilda Kilström, Jósef Sigurdsson, and Roine Vestman, 2017, "Household Debt and Monetary Policy: Revealing the Cash-Flow Channel," CEPR Discussion Paper No. DP12270. Available at SSRN: https://ssrn.com/abstract=3035264.

Francisco, Eva de, 2018, "Individual consumption heterogeneity and its implications for aggregate consumption.”

Gilchrist, Simon, David López-Salido, and Egon Zakrajšek, 2015, "Monetary Policy and Real Borrowing Costs at the Zero Lower Bound,” American Economic Journal: Macroeconomics, 7 (1): 77-109.

Guerrieri, Veronica, and Guido Lorenzoni, 2011, “Credit Crises, Precautionary Savings, and the Liquidity Trap.” National Bureau of Economic Research 17583.

Gürkaynak, Refet S., Brian Sack and Eric T. Swanson, 2005, "Do Actions Speak Louder Than Words? The Response of Asset Prices to Monetary Policy Actions and Statements" International Journal of Central Banking, Vol. No. 1, 55-93.

Gürkaynak, Refet S., Brian Sack and Eric T. Swanson, 2007, "Market-Based Measures of Monetary Policy Expectations," Journal of Business \& Economic Statistics, Vol. 25, 201212. 
Hanson, Samuel G., and Jeremy C. Stein, 2015, “Monetary policy and long-term real rates”, Journal of Financial Economics 115, 429-448

Hedlund, Aaron, Fatih Karahan, Kurt Mitman, and Serdar Ozkan, 2016, “Monetary Policy, Heterogeneity, and the Housing Channel.”

Hofmann, Boris, and Gert Peersman, 2017, “Is There a Debt Service Channel of Monetary Transmission?” Quarterly Review, Bank for International Settlements.

International Monetary Fund, 2017. “Household Debt and Financial Stability,” Chapter 2 in Global Financial Stability Report, October, (Washington: International Monetary Fund).

Jordà, Òscar, 2005, "Estimation and Inference of Impulse Responses by Local Projections,” American Economic Review, Vol. 95 No. (1), 161-182.

Justiniano, Alejandro, Giorgio Primiceri, and Andrea Tambalotti, 2015, "Household Leveraging and Deleveraging,” Review of Economic Dynamics, vol. 18 (January), 3-20

Kaplan, Gregg, Benjamin Moll, and Giovanni L. Violante, 2018, “Monetary Policy According to HANK,” American Economic Review, 108(3): 697-743.

Kaplan, Greg, and Giovanni Violante, 2014, “A Model of the Consumption Response to Fiscal Stimulus Payments,” Econometrica, Vol. 82 No. 4, 1199-1239.

Kaplan, Greg, and Giovanni Violante, 2018, "Microeconomic Heterogeneity and Macroeconomic Shocks,” Journal of Economic Perspectives, Vol. 32, No 3, 167-194.

Kaplan, Greg, Gianluca Violante, and Justin Weidner, 2014, “The Wealthy Hand-to-Mouth.” Brookings Papers on Economic Activity, No. 1, 77-138.

Luo, Wenlan, 2017, “The Consumer Credit Channel of Monetary Policy,” retrieved from Georgetown University DigitalGeorgetown repository, https://repository.library.georgetown.edu/bitstream/handle/10822/1043836/Luo_georgetown _0076D_13549.pdf?sequence $=1$

Melzer, Brian T., 2017, "Mortgage Debt Overhang: Reduced Investment by Homeowners at Risk of Default,” The Journal of Finance, Vol. LXXII, No. 2.

Mian, Atif, and Amir Sufi, 2014, "What Explains the 2007-2009 Drop in Employment," Econometrica, 82(6): 2197-2223

Mian, Atif, Amir Sufi, and Emil Verner, 2017, "Household Debt and Business Cycles Worldwide.” Quarterly Journal of Economics: 1-63. 
Mian, Atif, Kamalesh Rao, and Amir Sufi, 2013, "Household Balance Sheets, Consumption, and the Economic Slump,” The Quarterly Journal of Economics, Vol. 128, Issue 4, 1687-1726.

Narita, Futoshi and Machiko Narita, 2011, "Risk and Risk-Sharing.” Chapter 2 of "Essays in Uninsurable Income Risk and Household Behavior,” Machiko Narita (Eds.), retrieved from the University of Minnesota Digital Conservancy, http://hdl.handle.net/11299/112724.

Parker, Jonathan A., Nicholas S. Souleles, David S. Johnson, and Robert McClelland, 2013, “Consumer Spending and the Economic Stimulus Payments of 2008," American Economic Review, Vol 103 No. 6, 2530-53.

Ramey, Valerie. A., 2016. “Macroeconomic Shocks and Their Propagation.” In Handbook of Macroeconomics (Vol. 2, pp. 71-162), Elsevier.

Romer, Christina, D., and David H. Romer, 2004, “A New Measure of Monetary Shocks: Derivation and Implications,” American Economic Review, 94 (4): 1055-1084.

Souleles, Nicholas S., 1999, “The Response of Household Consumption to Income Tax Refunds,” American Economic Review, Vol. 89 No. 4, 947-958.

Stock, James H., and Mark W. Watson, 2018. "Identification and Estimation of Dynamic Causal Effects in Macroeconomics Using External Instruments.” The Economic Journal, 128(610), 917-948.

Sufi, Amir, 2015, “Out of Many, One? Household Debt, Redistribution and Monetary policy during the economic slump”, Andrew Crockett Memorial Lecture, BIS, 2015.

Wong, Arlene, 2015, "Population Aging and the Aggregate Effects of Monetary Policy". Available at SSRN: https://ssrn.com/abstract=2462555 Yellen, Janet, 2016, "Macroeconomic Research After the Crisis,” speech delivered at "The Elusive 'Great' Recovery: Causes and Implications for Future Business Cycle Dynamics” 60th annual economic conference sponsored by the Federal Reserve Bank of Boston, Boston, Massachusetts, https://www.federalreserve.gov/newsevents/speech/yellen20161014a.htm 


\begin{abstract}
APPENDiX I. DAta
The Consumer Expenditure Survey (CEX) is a survey conducted by the Census Bureau and is primarily used by the Bureau of Labor Statistics to determine the weights assigned to different goods and services in calculating the consumer price index (CPI). The CEX is a rotating panel survey and each household is interviewed once per every three months for, at most, 15 consecutive months. In addition, the survey sample is designed to be representative of the U.S. civilian non-institutional population.
\end{abstract}

\title{
Data cleanup
}

We take several steps to clean up the raw CEX data. We drop observations in which the CEX records negative consumption for households. We also drop observations for households with more than one consumption unit and households with less than four interview observations. This cleanup results in roughly 5,000 quarterly household observations, of which 74 percent are homeowners and 45 percent are homeowners with outstanding mortgage balance. On average, households spend $\$ 4,320$ on non-durable goods and $\$ 1,048$ on durable goods. Some summary statistics for housing tenure and consumption for the data are shown in Appendix I Table 1 below.

One peculiar feature of the CEX survey is that the interview quarter and the consumption quarters may not align perfectly. Each time a household is interviewed, they are inquired about their consumption expenditures over the three months prior to the month of interview. Since households may be interviewed during any month within a given quarter, the interview quarter does not necessarily correspond with the months for which the consumption data are acquired. We make the appropriate adjustments to the consumption data so that they align with their respective calendar quarters.

\section{Appendix I Table 1. Housing Tenure and Real Consumption}

\begin{tabular}{|c|c|c|c|c|c|}
\hline & \multirow[b]{2}{*}{$\begin{array}{c}\text { Share } \\
\text { (percent) }\end{array}$} & \multicolumn{2}{|c|}{ Average Level } & \multicolumn{2}{|c|}{ Average Growth } \\
\hline & & $\begin{array}{c}\text { Non- } \\
\text { Durable }\end{array}$ & Durable & $\begin{array}{c}\text { Non- } \\
\text { Durable }\end{array}$ & Durable \\
\hline Homeowners & 74 & 4,803 & 1,204 & 0.14 & -3.44 \\
\hline w/ mortgage & 45 & 5,286 & 1,397 & 0.02 & -4.02 \\
\hline w/o mortgage & 29 & 4,044 & 900 & 0.32 & -2.25 \\
\hline Renters & 26 & 2,935 & 601 & -0.23 & -4.26 \\
\hline All & 100 & 4,320 & 1,048 & 0.04 & -3.60 \\
\hline
\end{tabular}

Sources: CEX and authors' calculations.

Note: Consumption variables are in constant dollars $(2000 \mathrm{Q} 1=100)$ and winsorized at one percent of each tail. 


\section{Definitions of consumption variables}

Following Aladangady (2014), non-durable consumption consists of food, alcohol, tobacco, housing operations, utilities, gasoline, public transportation, personal care, reading, entertainment, apparel, healthcare, and education expenses. Durable consumption consists of expenditure on cars (new and used), furniture, and equipment. Appendix I Table 1 outlines the CEX variables used to construct non-durable and durable consumption variables.

Details of the CEX variables used in constructing non-durable and durable consumption variables are mentioned in Appendix I Table 2.

\section{Leverage and liquidity}

Most of the household balance sheet data are only available in the $5^{\text {th }}$ interview, while mortgage information is asked in every interview. Leverage is proxied by the ratio of mortgage balance to the reported house value. We aggregate the mortgage balances reported on all the properties owned by the household. The CEX variables used for constructing this are QBLNCM1X or QBLNCM2X, which report the household's mortgage balance at the beginning of the month, three months prior to the interview or two months prior to the interview, respectively. Our choice over which of the two variables to use depends on which month corresponds to the first month in the consumption quarter. If a household refinances its mortgage on a property, we adjust the household's mortgage balance such that the mortgage balances before and after refinancing are not double-counted. For property value we use PROPVALX. We construct a house price index using this variable and it matches well with the Case-Shiller Home Price Index, particularly the boom-bust in the house prices although it is not shown here.

Liquid assets include the total balance a household has in their checking and savings accounts. From 2013 onwards, liquid assets also include money market accounts and certificates of deposits. The CEX variables used in constructing the liquid assets variable are LIQUIDX for the period covering 2013-14 and CKBKACTX + SAVACCTX for 19942012. Unlike balance-sheet variables, income is reported in both the second and the fifth interview. We use the imputed after-tax income, FINCATXM from 2004 onwards. For the prior years, we use the reported after-tax income, FINCATAX, and replace invalid missing entries with imputed income data. Appendix Table 3 shows the correlation matrix among key variables.

\section{Cohorts and control variables}

We construct the synthetic cohorts using housing tenure (CUTENURE) and the household head's birth year, which is determined by the interview date and the household head's age (AGE_REF) at the time of the interview. The control variables used in the panel analysis include race (REF_RACE), education (EDUC_REF), age (AGE_REF), family size (FAM_SIZE), and marital status (MARITAL1). 


\section{Appendix I Table 2. Definitions of Key Consumption Variables}

\begin{tabular}{lll}
\hline \hline Variable & Details & CEX Name \\
\hline$C$ & Total Expenditure & TOTEXP
\end{tabular}

Non-durable Expenditure

Food

Alcohol

Tobacco

Housing operations

Utilities

Gasoline

Public transportation

Personal care

Reading

Entertainment

Apparel

Healthcare

Educational expenses

Durable Expenditure

Cars \& trucks, new

Cars \& trucks, used

Other vehicles

Furnishing \& equipment
FOOD

ALCBEV

TOBACC

HOUSOP

UTIL

GASMO

PUBTRA

PERSCA

READ

ENTERT

APPAR

HEALTH

EDUCA

CARTKN

CARTKU

OTHVEH

HOUSEQ

\section{Annex Table 3. Correlation Matrix}

\begin{tabular}{|c|c|c|c|c|c|c|c|c|c|}
\hline & $\begin{array}{l}\text { Non Durable } \\
\text { Consumption }\end{array}$ & $\begin{array}{c}\text { Durable } \\
\text { Consumption }\end{array}$ & LTV & Liquidity & $\begin{array}{l}\text { Family } \\
\text { Size }\end{array}$ & $\begin{array}{l}\text { College } \\
\text { Education }\end{array}$ & $\begin{array}{l}\text { Ethnicity } \\
(\text { white = 1) }\end{array}$ & $\begin{array}{l}\text { Marital } \\
\text { Status }\end{array}$ & $\begin{array}{l}\text { Reference } \\
\text { Age }\end{array}$ \\
\hline Non durable consumption & 1 & & & & & & & & \\
\hline Durable consumption & 0.045 & 1 & & & & & & & \\
\hline LTV & -0.0068 & -0.0068 & 1 & & & & & & \\
\hline Liquidity & 0.0098 & 0.0039 & -0.1774 & 1 & & & & & \\
\hline Family size & 0.0001 & 0.0004 & 0.2209 & -0.1502 & 1 & & & & \\
\hline College education & 0.0055 & 0.004 & 0.0839 & 0.0879 & -0.0121 & 1 & & & \\
\hline Ethnicity (white = 1) & 0.0056 & 0.0028 & -0.0481 & 0.0802 & -0.0351 & 0.0374 & 1 & & \\
\hline Marital status & 0.0055 & 0.0027 & 0.0821 & -0.0056 & 0.4539 & 0.1051 & 0.1163 & 1 & \\
\hline Reference age & 0.0078 & 0.003 & -0.4468 & 0.2449 & -0.3801 & -0.088 & 0.0589 & -0.0947 & 1 \\
\hline
\end{tabular}




\section{Appendix II. Synthetic Cohort Panel Data}

\section{Construction of Synthetic Cohort Panel}

To measure the responsiveness of households' consumption to monetary policy over time, we need a panel data, although the CEX is designed as repeated cross-section data (Appendix I). Therefore, we construct a synthetic panel, as in Attanasio and Davis (1996), Narita and Narita (2011) and Cloyne and others (2017). We construct synthetic cohorts based on the arguably time-invariant household characteristics, which are the birth year and housing tenure of the household head. That is, we construct a panel data set of each representative consumer unit with one of the combination of these characteristics.

The birth cohorts are defined by a 5-year band. The oldest cohort consists of people who were born between January 1910 and December 1914. We focus on household heads of age 25 to 75. The housing status is categorized into three levels: owners without mortgage, owners with positive mortgage balance, and renters. This procedure yields an unbalanced panel of 42 synthetic cohorts with a minimum of 20 CUs in each of them.

Our choice of a small set of characteristics is driven by the objectives of avoiding having few CUs in some synthetic cohorts, and avoiding short time series. The number of CUs in a synthetic cohort varies across cohorts. This variation in the number of CUs in synthetic cohorts can be problematic. The time-series data of synthetic cohorts with few CUs tend to be much volatile than that of synthetic cohorts with many CUs, because household-specific changes in consumption are not averaged out. This leads to high standard errors for synthetic cohorts with few CUs. Also, if the time-series of consumption and income are too short, estimation may suffer from a small sample bias.

\section{Estimation of Cohort-Level Variables}

Given the definition of synthetic cohorts, we estimate durable and non-durable consumption paths for each cohort. We consider a reduced form relationship between cohort-level consumption and individual household-level consumption in the cohort as follows:

$$
\log \left(c_{j, i, t}\right)=\log \left(c_{i, t}\right)+\varepsilon_{j, i, t}, \quad \varepsilon_{j, i, t} \sim \text { i.i.d. }\left(0, \sigma_{i, t}^{2}\right)
$$

where $c_{j, i, t}$ is consumption level of household $j$ in cohort $c$ at time $t, c_{i, t}$ is cohort-level consumption for cohort $i$ at time $t$, and $\varepsilon_{j, i, t}$ is a household-specific idiosyncratic shock at time t, which has mean zero and variance $\sigma_{i, t}^{2}$. That is, we model log of individual consumption as a random draw from a distribution with mean $\log \left(c_{i, t}\right)$ and variance $\sigma_{i, t}^{2}$.

In this reduced form model, the simple average of $\log \left(c_{j, i, t}\right)$ over households in cohort c at time $\mathrm{t}$ is a consistent estimate of $\log \left(c_{i, t}\right)$ by the law of large numbers. Since the CEX is a random sample from U.S. population, we use the CEX sample weights in taking the average. 
We interpret the CEX sample weights as the number of off-sample households who are represented by the consumer unit in the sample. Namely, we consider that there are $\omega_{j, i, t}$ households who are similar to household $i$, and hence whose consumptions are equal to $c_{j, i, t}$. Therefore, our estimate of cohort-level logged consumption is the weighted average of logged consumption expenditures over households in the cohort, using the CEX sample weights. That is,

$$
\begin{gathered}
\log \widehat{\left(c_{l, t}\right)}:=\frac{1}{\omega_{i, t}} \sum_{j \in I_{i, t}} \omega_{j, i, t} \log \left(c_{j, i, t}\right) \\
\log \left(c_{i, t}\right):=1
\end{gathered}
$$

where $I_{i, t}$ is the set of households in cohort $i$ at time $t, \omega_{j, i, t}$ is the CEX sample weights, and $\omega_{i, t}:=\sum_{j \in I_{i, t}} \omega_{j, i, t}$. 